Board of Governors of the Federal Reserve System

International Finance Discussion Papers

Number 1084

July 2013

\title{
Say on Pay Laws, Executive Compensation, CEO Pay Slice, and Firm Value around the World
}

\author{
Ricardo Correa \\ Ugur Lel
}

NOTE: International Finance Discussion Papers are preliminary materials circulated to stimulate discussion and critical comment. References to International Finance Discussion Papers (other than an acknowledgment that the writer has had access to unpublished material) should be cleared with the author or authors. Recent IFDPs are available on the Web at www.federalreserve.gov/pubs/ifdp/. This paper can be downloaded without charge from the Social Science Research Network electronic library at www.ssrn.com. 


\title{
Say on Pay Laws, Executive Compensation, CEO Pay Slice, and Firm Value around the World
}

\author{
Ricardo Correa \\ Federal Reserve Board \\ Ugur Lel* $^{*}$ \\ Virginia Tech - Pamplin College of Business
}

First draft: March 2013

This draft: June 2013

\begin{abstract}
This paper examines the effects of say on pay (SoP) laws on CEO compensation, the portion of top management pay captured by CEOs, and firm valuation. Using a large cross-country sample of about 103,000 firm-year observations from 39 countries, we document that compared to our control group of firms, SoP laws are associated with 1) a lower level of CEO compensation, which partly results from lower CEO compensation growth rates and is related to CEO power, 2) a higher pay for performance sensitivity suggesting that SoP laws have the greatest effects on firms with poor performance, 3) a lower portion of total top management pay awarded to CEOs indicating lower pay inequality among top managers and 4) a higher firm value, which is related to whether the CEO's share of total top management pay was relatively high before the laws are passed. Further, while both mandatory and advisory SoP laws are associated with lower CEO pay levels, only advisory SoP laws tighten the sensitivity of executive pay to firm performance. Collectively, our results document significant changes in executive compensation policies and firm valuation following the passage of SoP laws around the world.
\end{abstract}

JEL Classification Codes: G15, G34, G38, M12

Keywords: Executive compensation, say on pay laws, regulations, pay structure, CEO pay slice, firm valuation, corporate governance.

\footnotetext{
* We would like to thank Mark Carey, Darius Miller, Karen Selody, and seminar participants at the Federal Reserve Board and the International Monetary Fund for their helpful comments. Greg Cohen and Jason Goldrosen provided excellent research assistance. The views in this paper are solely the responsibility of the author(s) and should not be interpreted as reflecting the views of the Board of Governors of the Federal Reserve System or of any other person associated with the Federal Reserve System.

Ricardo Correa is a senior economist at the Federal Reserve Board (Ricardo.Correa@frb.gov), Ugur Lel is an assistant professor of finance at the Pamplin College of Business at Virginia Tech (ulel@vt.edu).
} 


\section{Say on Pay Laws, Executive Compensation, CEO Pay Slice, and Firm Value around the World}

$[\mathrm{O}]$ ur interest is in ensuring that in this matter - as in other areas of corporate governance - the shareholders who own a company receive the information they need to make an informed judgment, and that they have a vehicle through which they can express that judgment to the board.

-SEC Chairman Mary Schapiro, November 2, 2011

Events such as the option backdating scandal and large severance packages to CEOs of insolvent firms during the recent global financial crisis have reintensified the long-standing debate on the determinants of executive pay among investors, academics, and lawmakers. In particular, several studies argue that current $\mathrm{CEO}$ compensation policies are best explained by the rent-seeking behavior of powerful managers (e.g., Bebchuk, Fried, and Walker (2002), Bebchuk and Fried (2003, 2005)), while others contend that CEO compensation is the outcome of an efficient bargaining process in the labor market (e.g., Holmstrom (1979), Core, Guay, and Larcker (2003)). In line with the former argument, twelve countries have recently passed laws to give shareholders more say on executive compensation (henceforth, say on pay -SoP- laws). The United Kingdom was the first country to adopt such laws and the United States passed its version of SoP laws in 2010 as a provision in the Dodd-Frank Act.

Perhaps not surprisingly, these laws initiated a new debate: How effective are they in aligning executive pay practices with shareholders' interests? Advocates of SoP laws argue that giving shareholders a say on compensation can empower and incentivize boards of directors in their negotiations with CEOs, potentially increasing accountability, linking firm performance to pay more strongly, and reducing pay levels (e.g., Bebchuk, Friedman, and Friedman (2007), Coates (2009), Davis (2007)). Further support for this view is the evidence that CEOs have significant influence over board composition, and the monitoring of the management matters for CEO compensation (e.g., Shivdasani and Yermack (1999), Core et al. (1999), Bebchuk (2003), Hartzell and Starks (2003), Coles, Daniel, and 
Naveen (2007), Cai, Garner, and Walkling (2009)). In contrast, some critics stress that SoP laws may lead to suboptimal pay practices (e.g., Kaplan (2007), Bainbridge (2008), Gordon (2009)) with a negative effect on the valuations of some firms (Larcker, Ormazabal, and Taylor (2011)), and that pension funds' actions on executive compensation may be driven by some political agendas, potentially destroying shareholder value (Bainbridge (2011), Larcker and Tayan (2012a)). ${ }^{1}$ Alternatively, SoP laws may have no effect on compensation policies and firm valuation because market forces in place are already sufficient. The main stated purposes of these laws are to curb the seemingly high levels of CEO pay, tighten the link between firm performance and CEO pay, and improve disclosure on executive compensation. Historically, regulatory changes have had a major influence on patterns in executive compensation, with some regulations causing unintended effects on executive compensation (e.g., see Murphy (2013) for a detailed discussion).

Our paper adds to this debate by using a large cross-country sample of firms to analyze the effects of binding and advisory SoP laws on 1) CEO compensation (i.e., the intended consequences), 2) the share of total managerial pay captured by the CEO (i.e., an unintended consequence), and 3) firm valuation. We document that compared to our control group of firms, SoP laws have reduced the CEO's portion of top management pay and this reduction has led to an increase in firm value. Our findings also complement the prior evidence on SoP laws which focuses on either the United States or the United Kingdom and finds mixed results on the impact of SoP laws on firm value and CEO pay (Cai and Walkling (2011), Larcker et al. (2011), Ferri and Maber (2013)). We find that firms subject to SoP laws experience a lower CEO pay growth and higher valuation. We also contribute by using the largest cross-country sample on CEO compensation to date and by controlling for any confounding effects of contemporaneous unobserved firm shocks using a holdout sample of countries that did not

\footnotetext{
${ }^{1}$ See Yermack (2011) for a review of the literature on shareholder voting and elections as part of the corporate governance
} environment. 
implement SoP laws. Moreover, we are able to exploit the variation in the characteristics of SoP laws across countries to test which elements of these laws have the greatest effect on CEO compensation policies and firm value.

In the first part of our analysis, we find that SoP laws are associated with a lower level of CEO compensation in our international sample of about 103,000 firm-year observations. The average CEO pay declines by $6.1 \%$ for firms in countries that pass SoP laws compared to the pre-SoP period and to firms in countries that do not pass such laws. This decrease comes from the lower CEO pay growth for firms subject to SoP laws: While the average predicted CEO pay increases by $5.5 \%$ for countries that pass SoP laws during the sample period, it increases by $8.1 \%$ for the control group. We also find a higher pay for performance sensitivity for SoP countries following the enactment of the laws. These findings are consistent with the stated objectives of SoP laws. Our results show that CEO pay is lower following the passage of SoP laws for firms with greater CEO power as measured by board busyness and CEO tenure, and for firms with higher shareownership by institutional investors that are potentially passive (bank trusts, insurance companies and pension funds).

In the second part we examine whether SoP laws change the CEO pay slice (CPS), defined as the share of total compensation awarded to the CEO relative to that of the five highest-paid executives in a firm. These tests use the pay on senior managers as the control sample when analyzing the effect of SoP laws on CEO pay, and are less subject to endogeneity concerns, as the firm-specific effects on the level of CEO pay are perfectly controlled for. CPS has been explained by prior studies as the outcome of a tournament set by the board of directors or shareholders to provide incentives to non-CEO executives to induce greater effort (Lazear and Rosen (1981)), or by the dominant position of the CEO within the firm to extract higher pay (e.g., Bebchuk, Cremers, and Peyer (2011)). We document that SoP laws are associated with lower compensation gaps between the CEO and other top-ranked 
managers. The way this occurs is through a decrease in CEO pay and no significant change in senior management pay, thereby making managerial pay more equal within the firm's management team.

In the third part of our analysis, we test whether this change in CPS affects firm value and analyze the overall impact of SoP laws on firm value. Results show an average increase of $3.6 \%$ in the industry-adjusted Tobin's Q around the adoption of SoP laws. The improved alignment of CEO pay to firm performance and a lower CPS are two potential channels through which SoP laws increase firm value. Given that the pay differentials amongst the management team is not among the stated objectives of SoP laws, our results show that an unintended consequence of the laws is that the managerial pay gap decreases and consequently firm value increases.

SoP laws are not homogenous in their content across countries. The most important difference in SoP laws is whether the board of directors has to address shareholder disapproval of executive pay (binding SoP votes as required by Norway and Sweden) or not (advisory SoP laws as in the US and Australia), even though companies are required in both cases to put the compensation policy up for shareholder voting on a periodical basis. The advisory feature of SoP laws has drawn criticism from several activist shareholders in the US. ${ }^{2}$ As Larcker, McCall, Ormazabal, and Tayan (2012b) argue, there is no evidence on which of these approaches provides the best response to compensation related problems. Our results show that while the level of CEO pay is lower by similar amounts in the case of both binding and advisory SoP laws, the effect of binding laws is only marginally significant. In addition, only advisory SoP laws are associated with a greater alignment of pay to firm performance. Thus, advisory laws appear to affect executive compensation in a way that is consistent with two of the

\footnotetext{
${ }^{2}$ For example, the first set of votes on SoP in the US were set in 2011 and shareholders in approximately 40 companies failed to garner a majority for the SoP proposals. In 13 of these 40 cases, the companies faced lawsuits brought by shareholders (e.g., see Romanchek and Meyer (2013)). Further, UK policymakers have recently announced that they may convert existing advisory SoP laws into binding ones.
} 
main objectives of SoP laws.

SoP laws might be an outcome of recent changes in compensation levels and economic activity in the country. To ensure our results are not fully picking up such pre-law business environment in the country, we use the variation in the political environment in the country around the passage of SoP laws as well as the general attitude of people within the country towards differences in effort leading to differential pay levels as instruments for the likelihood of passing SoP laws. Studies that analyze the determinants of regulatory changes find that 'the partisan composition' of the ruling government is associated with the likelihood of reforms (e.g., Kroszner and Strahan (1999)). We also include firm fixed effects and industry*year fixed effects to mitigate concerns that our results reflect the effects of omitted constant and time-varying variables in the post-law period. We find that our main results are robust to these additional tests.

Our paper contributes in several important ways to the evidence on the impact of SoP laws on compensation policies and firm valuation. We provide the first empirical evidence on the managerial pay inequality and related firm valuation effects of SoP laws, which also contributes to the strand of literature on CPS and tournament incentives. For identification purposes, we use SoP laws in our tests on the relation between managerial pay inequality and firm value. Our findings imply that CPS partially reflects management entrenchment, consistent with the findings of Bebchuk et al. (2011).

Further, most studies assessing the impact of SoP laws have focused on individual countries, particularly the UK and US and the evidence on the impact of SoP laws on CEO pay and firm value are thus far inconclusive (e.g., Cai and Walking (2011), Larcker et al. (2011), Ferri and Maber (2013)). Our dataset allows tests for the effects of SoP laws on executive pay and firm value in a country while controlling for pay practices and contemporaneous unobserved firm shocks in countries that have not implemented SoP laws. Our cross-country setting allows us to exploit differences across countries in 
the characteristics of the SoP laws to test which elements of these laws are the most effective. We show that, for example, unlike advisory SoP votes in the UK and US, binding SoP laws are not associated with an improved pay for performance sensitivity. Our tests potentially also have greater power there is greater variation in the severity of agency conflicts at the firm and country levels in our sample.

Our paper also adds to the rich literature on the relation between shareholder influence and executive compensation, as we think of SoP laws as a shareholder empowerment mechanism that may better align the interests of managers and shareholders. In this aspect, our paper contributes to the nascent group of cross-country studies on executive compensation using the largest sample on executive compensation to date (Fernandes, Ferreira, Matos, and Murphy (2013), Burns, Minnick, and Starks (2013), Bryan, Nash, and Patel (2010)). Our paper is also related to studies on the effectiveness of firm-level measures of shareholder influence such as shareholder proposals and the associated voting outcomes on governance provisions (e.g., Cai et al. (2009), Ertimur, Ferri, and Muslu (2011), Iliev, Lins, Miller, and Roth (2012)). Unlike these studies, which provide important insights into shareholder-initiated proposals' effects on compensation, we use a country-level change in the ability of shareholders to input more say on CEO compensation. Thus, concerns regarding the impact of selection biases on tests are mitigated in our analysis. Finally, we expand the literature on the effect of regulation on executive compensation by analyzing the effects of SoP laws in a cross-country sample.

The rest of the paper is organized as follows. Section 1 presents sample construction and descriptive statistics. Section 2 overviews the empirical specification and presents the results on the effects of SoP laws on CEO compensation policies. Section 3 analyzes changes in CPS in relation to SoP laws and Section 4 focuses on firm valuation effects of SoP laws. Section 5 provides robustness checks. Section 6 reports the differential effects of binding and advisory SoP laws on executive compensation policies and firm value and Section 7 concludes. 


\section{Sample construction and CEO compensation}

There are two main sources of managerial compensation data for cross-country studies: S\&P's Capital IQ (CIQ) and BoardEx. Earlier studies such as Fernandes et al. (2013), Ferri and Maber (2013), and Ozkan, Singer, and You (2013) focus on BoardEx, but more recent studies like Balsam, Gordon, Li, and Runesson (2013) and Burns et al. (2013) use CIQ. Our comparison of the two datasets results in favor of CIQ in terms of coverage. The sample size for all countries excluding the US is about 6 times larger in CIQ than in BoardEx across various regressions specifications in our tests. ${ }^{3}$ Thus, we use the executive compensation data from CIQ in our analysis.

The CIQ database includes detailed historical data on compensation for senior managers and directors for 119 countries between 1997 and 2012 from both public and private sources. CIQ reports information on total pay as well as a breakdown of its components such as salary, bonus, and equity pay, which is further broken down between restricted stock awards, stock grants, and long term incentive plans in local currency at the individual level. We use the end of year exchange rates from the World Development Indicators database and http://www.x-rates.com to convert compensation data into \$US. CIQ also provides information on the career tracks of managers, from which firm governance characteristics such as board size and board independence, and manager characteristics such as the title, committee membership, and the number of directorships can be identified.

\footnotetext{
${ }^{3}$ For example, the regression specification in column (1) of Table 2 would have a sample size of around 14,000 observations if we used BoardEx, about $90 \%$ of which would be dominated by US and UK firms. We also find the CIQ compensation data are highly reliable. The disadvantage of CIQ compared to BoardEx, however, is that it lacks detailed information on the managers such as gender and educational background. Because of insufficient information on CEO characteristics, we do not include CEO age and tenure in our main tests. However, our results are robust to the inclusion of these variables as reported in Table 2 in the Appendix.
} 
There are about 1.5 million unique observations with non-missing total compensation data for managers and directors between 2001 and 2012 in the CIQ dataset. ${ }^{4}$ Since we are primarily interested in the effects of SoP laws on CEO compensation and firm value, we only keep around 205,000 observations where the top executive of the firm is identifiable and the corresponding observation in CIQ is for the top executive. ${ }^{5}$ We then merge this dataset with the Worldscope database using CIQ and Thomson Reuters mapping databases that provide links among commonly used firm identifiers such as GVKEY in the CIQ database and ISIN, SEDOL, and WorldscopeID in the Worldscope database, and DScode in the Datastream database. We manually match the remaining unmatched observations by company name. Worldscope is the main source for firm-specific financial characteristics in our tests, and this matching strategy results in around 155,000 observations. However, missing information on variables such as net sales and stock returns leads to a sample of 106,000 observations. Further excluding firms with assets less than $\$ 1$ million and countries with fewer than 30 observations cause our final sample to drop to around 103,000 firm-year observations and 20,300 firms from 39 countries as reported in Table 1. Panel A of Table 1 displays the distribution of our regression sample by country and information on the SoP law status of each country.

We construct several variables using CIQ in our analysis. The first one is total CEO pay, defined as total annual compensation of the CEO, which includes salaries, bonuses, restricted stock and option awards, long-term incentive plans, changes in pension plans, and all other compensation measured in US\$. Option awards and other equity based compensation (i.e., restricted stock awards) are as reported by companies, and option values are based on share prices at year end. We also create variables to

${ }^{4}$ CIQ starts in 1997. However, information on total CEO compensation with complete firm-specific financial data is sparsely populated prior to 2001. Thus, our sample starts from 2001.

5 CIQ reports managerial title mainly through the variable 'profunctionname'. We label managers with a profunctionname value of chief executive officer or $\mathrm{CEO}$ as the top executive. If there is no manager with such a title, we look for managers with titles such as president, managing director, and general manager in the database as in Fernandes et al. (2013) and Lel and Miller (2008). For firms with no identifiable top executive, we use the exact title of the manager in the database to find out the top executive. For joint CEOs, we take the average of the respective variables across both managers. We drop observations where the manager's title includes 'former'. We use the terms CEO and top executive interchangeably throughout the paper. 
capture the CEO pay structure: the portion of total CEO pay in the form of equity-based compensation (equity pay/CEO pay) as well as the natural logarithms of equity-based CEO pay and non-equity based CEO pay. The final compensation-based variables we compute measure how much of total management pay among the five highest-paid managers is captured by the CEO. The first variable is CEO pay slice (CPS). Following Bebchuk et al. (2011) we define CPS as the percent of total annual compensation of the five highest-paid managers claimed by the CEO. A similar measure is pay gap, which is the difference between total CEO pay and the median value of annual compensation of the five highest-paid managers (e.g., Kale, Reis, and Venkateswaran (2009), Burns et al. (2013)). A higher portion of the top management pay captured by the CEO can be a result of the relative talent of the $\mathrm{CEO}$ or the relative power of the $\mathrm{CEO} .^{6}$

Panel B of Table 1 provides summary statistics for our CEO compensation and control variables used in the regression analysis. The average total CEO pay is $\$ 1.24$ million, which is lower than the $\$ 2$ million average reported in Burns et al. (2013) and \$4.2 million Fernandes et al. (2013). A close inspection of this statistics suggests that lower average CEO pay in our sample is mostly due to the larger sample size and a higher proportion of smaller firms than in other studies. For example, the average sales in our sample are $\$ 1,230$ million compared to $\$ 2,662$ million in the overall sample of Burns et al. (2013). If we restrict the sample to firms with sales greater than $\$ 100$ million, the average CEO pay in our sample goes up to $\$ 2.15$ million, which is similar to the average of $\$ 2$ million in Burns et al. (2013). Similarly, if we restrict the sample to firms with sales greater than $\$ 500$ million, our statistics on CEO pay and firm sales become more comparable to that in Fernandes et al. (2013). ${ }^{7}$

\footnotetext{
6 In calculating these variables, we impose the restriction in our dataset that we have total pay figures for at least two executives excluding the CEO.

7 The average sales (CEO pay) figures are $\$ 5.08$ billion and $\$ 5.7$ billion ( $\$ 3.58$ million and $\$ 4.2$ million) in this subsample of our sample and the Fernandes et al. (2013) sample, respectively.
} 
Panel B also shows that the average CPS is $47 \%$, which is larger than the average CPS of $35.7 \%$ reported by Bebchuk et al. (2011) for US firms between 1993 and 2004.

\section{Say on Pay Laws and CEO Compensation}

\subsection{Empirical approach}

In this paper we examine the effects of binding and advisory SoP laws on CEO compensation policies, the share of total managerial pay captured by the CEO, and firm valuation in a cross-country sample. The SoP laws can influence compensation policies in several ways. First, in settings where the CEO is powerful enough to extract rents in the form of compensation, and directors are ineffective, SoP laws can empower the board of directors to negotiate better terms with the CEO through the use of (or the threat of) explicit shareholder support as leverage (e.g., Bebchuk et al. (2007), Coates (2009)). Second, concerned about re-election and their (and their firms') reputation, directors are likely incentivized to act on direct shareholder input through SoP votes on compensation (e.g., Ferri and Maber (2013), Grundfest (1993)). Third, SoP votes can improve communication between the board of directors and shareholders on compensation and other corporate policies (e.g., Davis (2007), Alissa (2009)). In order to examine the impact of SoP laws on CEO compensation policies, we estimate the following panel data regression between 2001 and 2012:

$$
\begin{aligned}
& \log \left(\text { Total CEO pay }_{i t}=a+\beta^{*} S_{0} P_{i t}+\gamma^{*} \text { Firm performance }_{i t-1}+\lambda^{*} \text { SoP }_{i t} * \text { Firm performance }_{i t-1}+\delta^{*}\right. \text { firm } \\
& \text { controls } s_{i t-1}+\eta^{*} \text { country and industry controls } s_{i t-1}+\theta^{*} C E O \text { controls }_{i-1}+\mu^{*} \text { year controls } \text { it-1 }+\varepsilon_{i t}
\end{aligned}
$$

where the dependent variable is the natural logarithm of total CEO pay for firm $i$ in year $t, S_{0} P$ is a dummy variable that equals one for the time period following the staggered passage of SoP laws, if any, and zero otherwise. Firm performance is either industry-adjusted stock returns or ROA in year t-1, firm characteristics measure firms' other financial and governance conditions in year $t-1$, country and industry 
characteristics are factors related to the macro economic conditions of the country and the sectoral growth opportunities worldwide measured as of $t-1$. We use the industry-adjusted stock returns as our main measure of firm performance. Equation (1) also includes firm and year fixed effects. The firm fixed effects specification allows us to fully exploit the panel nature of our dataset and to control for unobserved heterogeneity that is not captured by the time-varying firm characteristics in the empirical specification. In examining the relation between SoP laws and CEO compensation, we control for other variables that are documented by prior literature to influence CEO compensation (e.g., Core et al. (1999), Fernandes et al. (2013)). We discuss these variables in detail in the next section. We compute robust standard errors using Roger's method of clustering at the firm level that controls for possible serial correlation and heteroscedasticity.

Because we examine the change in CEO compensation before and after SoP law enactment between the firms in countries with and without SoP laws and we consider the within-firm variation in CEO compensation while controlling for year effects, the regression specification in equation (1) does not control for CEO characteristics such as CEO education, age, and tenure. To the extent that such characteristics change substantially between the pre and post periods within each sample firm, our coefficient estimates on SoP-related variables may be biased. We run regressions where we control for CEO turnover (in panel $\mathrm{C}$ of Table 8) and CEO age and tenure (in Table 2 in the Appendix), and find that our results are robust to these considerations.

\subsection{SoP Laws and Executive Compensation}

The results from estimating the regression specification in equation (1) are reported in Table 2. As in Fernandes et al. (2013), we start with the most parsimonious version of the specification in equation (1), where the independent variables are the natural log of firm sales to control for firm size and complexity, the SoP dummy, firm performance measured as the industry adjusted stock returns, 
and its interaction term with the SoP dummy in addition to firm and year fixed effects. The results from this model are reported in column (1). It shows that SoP dummy has a negative coefficient that is statistically significant at the one percent level $(-0.063, \mathrm{t}=-5.43)$, suggesting that SoP laws are associated with lower CEO compensation compared to the control group of the pre-SoP period in countries that pass SoP laws and of firms in countries that never pass such laws during the sample period. The coefficient estimate of -0.063 reflects a decrease of $6.1 \%$ decrease in CEO pay, which translates into about $-\$ 75,700$ on average given that the average CEO compensation is $\$ 1.24$ million. This result differs from the prior country-specific studies that find no change in the level of CEO pay around the adoption of SoP laws in the US and the UK (e.g., see Ferri and Maber (2013) for the UK and Iliev and Vitanova (2013) for the US). The main difference between our paper and these studies is that we control for any confounding effects of contemporaneous unobserved firm shocks using a holdout sample of countries that did not implement SoP laws.

The coefficient on the interaction term between SoP and firm performance is positive and statistically significant $(0.054, \mathrm{t}=8.59)$, suggesting that the link between $\mathrm{CEO}$ pay and performance tightens following the enactment of SoP laws. The positive and significant coefficient on the interaction term also suggests that $\mathrm{CEO}$ compensation in firms with superior performance is not affected, as the positive coefficients on both firm performance and SoP*firm performance outweighs the negative coefficient on SoP for firms with one standard deviation above the median industry adjusted stock returns (with the average effect of SoP being a 1.79\% increase in CEO pay). For a firm with the same firm performance, CEO pay will increase by $2.92 \%$ if the SoP laws are not passed. ${ }^{8}$ Examining the effect of SoP laws on CEO compensation policies in the UK, e.g., see Ferri and Maber (2013) also find that SoP laws are associated with a stronger link between CEO pay and firm performance. This

\footnotetext{
8 The first percentage term is calculated as $\exp [-0.063+0.030 *(0.005+0.956)+0.054 * 1 *(0.005+0.956)]-1=1.79 \%$. The second is calculated as $\exp [0.030 *(0.005+0.956)+0.054 * 0 *(0.005+0.956)]-1=2.92 \%$.
} 
column displays positive and statistically significant coefficients on firm performance and firm size, consistent with prior research (e.g., Fernandes et al. (2013)).

In the next columns we introduce additional firm, industry, and country controls to the specification in column (1) and use alternative measures of firm performance. We continue to find that SoP laws are associated with lower CEO compensation and a greater pay for performance sensitivity. Specifically, in column (2) we include leverage and stock return volatility, GDP growth, inflation rate, and the average market-to-book ratio within each industry as additional controls. The coefficients on SoP and the interaction term between SoP and firm performance remain similar in magnitude and significance. ${ }^{9}$ In column (3) we also control for the corporate ownership structure; inside and institutional ownership percentages, and in the fourth column we further control for corporate board structure (board independence, board size, and whether the COE is also the chairman) and the number of directorships held by the CEO. As we add more controls, the sample size drops. For example, the sample size is 89,056 observations in column (4) compared to 103,339 observations in the first column that only controls for firm performance and size.

In the final column we replace industry-adjusted stock returns with the industry-adjusted ROA, and continue to find that SoP laws influence $\mathrm{CEO}$ compensation in a similar fashion as in the previous columns. In addition, we consider regressions where we include both the current and one-year lagged values of firm performance and their interaction terms with SoP, and find positive and statistically significant coefficients on all four variables (reported in Table 2 in the Appendix). We also estimate a regression specification where we control for CEO age and tenure and report the results in Table 2 in the Appendix. This panel shows that our results on SoP laws are robust to these additional controls.

When we run separate regressions for those countries that passes SoP laws (as reported in Table 3

9 A detailed discussion of results on control variables in this table are provided in the Appendix. 
in the Appendix), we still find a greater sensitivity of CEO pay to firm performance in the post-law period. However, we cannot detect any change in the level of CEO pay associated with SoP laws. In fact, when we estimate equation (1) separately for each country, the pay levels increase in some countries. ${ }^{10}$ This finding shows that it is crucial to fully control for variation in pay and firm characteristics across countries with and without SoP laws when analyzing the effectiveness of SoP laws on compensation policies. Further, it implies that even though CEO compensation has increased in several SoP countries including the US and UK, the growth in CEO pay is higher in countries without SoP laws. Figure 1 shows the estimated growth in CEO pay in our sample, plotted separately for countries with and without SoP laws for every year after we control for firm, industry, and country characteristics. In particular, it presents the estimated CEO pay levels over time for SoP and non-SoP observations for a hypothetical firm with $\$ 1$ billion in sales and average values of other variables based on the regression specification in column (4) of Table 2. It shows that the growth in CEO pay is much higher for the control group of firms not subject to SoP laws. The average predicted CEO pay increases by $5.5 \%$ for countries that pass SoP laws during the sample period whereas the increase is $8.1 \%$ for the control countries that never pass such laws during the same time period. Thus, this figure shows that SoP laws are associated with lower compensation growth, which in turn drives the negative and statistically significant coefficient on SoP reported in Table 2.

Overall, Table 2 provides strong empirical evidence that SoP laws are associated with lower CEO pay. This finding is consistent with the stated objective of SoP laws under the presumption that CEOs were paid excessively prior to the enactment of these laws. In general, however, it is challenging to quantify the excess portion of total CEO pay, if any exists. While a decrease in CEO pay can be due to deterioration in the economic activity of the firm or the country, this explanation

\footnotetext{
${ }^{10}$ For example, the coefficient on SoP is $0.245(\mathrm{t}=4.53)$ and the coefficient on the interaction term between SoP and firm performance is $0.11(\mathrm{t}=4.36)$ in the US.
} 
is unlikely because we control for firm, industry, and country financial performance in our regression analysis, and use a control sample of countries that are subject to similar global country and industry shocks. Table 2 also shows that SoP laws are related to a greater link between CEO pay and firm performance, which is also consistent with the objectives of these laws.

In the remainder of our analysis, we use the regression specification in column (4) that includes various controls for firm financial characteristics, ownership and board structure, CEO's number of directorships, and country and industry growth. ${ }^{11}$

\subsection{CEO Power and Monitoring Intensity Effects}

We next test if the realized changes in pay policies around SoP laws are related to the degree of $\mathrm{CEO}$ influence and the monitoring of the management by including measures of CEO power and monitoring intensity in equation (1) along with their interaction terms with SoP and SoP*firm performance one at a time. If SoP laws increase shareholder influence and strengthen the ability of the board of directors in its negotiations with the CEO, we should observe greater effects of SoP laws at firms with more powerful CEOs and weaker monitoring of the management. Our measures are board busyness, CEO tenure, board independence, and grey and independent institutional ownership. Following the prior literature, we expect firms to have a better monitoring of the management when institutional ownership and board independence are high, and a worse governance environment and greater CEO influence when the board consists of busy directors and when CEO tenure is longer (e.g., see Core et al. (1999), Fich and Shivdasani (2006), Adams, Hermalin, and Weisbach (2010), Cai and Walkling (2011), and Fernandes et al. (2013)).

\footnotetext{
11 Including additional controls in equation (1) such as whether a non-US firm is cross-listed on a U.S. exchange and the ratio of foreign sales to net sales to control for the degree of internationalization has immaterial effect on our main results.
} 
Results from these regressions are reported in Table 3. In column (1) we test the effects of board busyness on $\mathrm{CEO}$ compensation and its sensitivity to firm performance around the time of the passage of SoP laws. We measure board busyness as the average number of directorships for the entire board of directors. A higher average is indicative of a busier board. Table 3 shows that CEO pay is lower and CEO pay becomes more sensitive to firm performance for firms with busier boards in the post-SoP period. Given that busy boards are generally associated with worse monitoring of the management, these results suggest that SoP laws improve the alignment of executive compensation with firm value and reduce CEO pay when the board is not an effective monitor (e.g., Core et al. (1999)). In the second column, we use the tenure of the CEO measured in years to proxy for the relative strength of the board of directors to monitor the firm's top manager. Longer CEO tenure is regarded as a greater ability of the CEO to exert influence on the board of directors (e.g., Ryan and Wiggins (2004), Boone, Field, Karpoff, and Raheja (2004)). Results show that the level of CEO pay is lower when CEO tenure is longer subsequent to the SoP laws' enactment, implying an effect similar to that documented for busy boards. In the next column we use the independent director percentage on board as a proxy for the degree of monitoring of managers. Results show that the level of CEO pay is higher in the post-SoP period for firms with more independent boards but this effect is not statistically significant.

In the remaining columns we decompose institutional ownership into two components based on the empirical evidence on institutional shareholders' involvement in the management of firms. Several studies show that mutual funds and investment advisers (independent institutional investors) are effective monitors of managers as they are more likely to directly influence management behavior by sitting on the board of directors (e.g., Aggarwal, Erel, Ferreira, and Matos (2011)). On the other hand, other institutional investors such as bank trusts, insurance companies, pension and endowment funds (grey institutional investors) are potentially less active, and rely more on indirect methods to influence 
corporate decision making such as through the threat of exit (e.g., McCahery, Sautner, and Starks (2012)). ${ }^{12}$ SoP laws can enhance the monitoring role of such potentially passive institutional investors by providing a more influential platform for them to have their views heard by the board of directors and other shareholders. The results in the final two columns of Table 3 show that a higher level of ownership by grey institutional investors is associated with a lower level of CEO pay and a greater sensitivity of CEO pay to firm financial performance, implying that such shareholders use SoP as a platform to influence firms' compensation policies. There is no such effect of mutual funds and investment advisers with respect to SoP laws.

Overall, our results provide some evidence that SoP laws are associated with lower CEO pay and to some extent a stronger sensitivity of CEO pay to firm performance in firms where CEOs are likely more powerful. Thus, SoP laws matter when the board of directors does not have a strong negotiation position vis-a-vis the CEO. Further, the effects of SoP laws on CEO compensation policies are greater in the case of institutional investors that are potentially passive shareholders. However, an important caveat with these results is that the statistical significance of key variables is weak, warranting caution in interpreting them.

\subsection{SoP Laws and CEO Compensation Structure}

In this section, we complement the previous analysis with an examination of the impact of SoP laws on the structure of CEO compensation. Specifically, we test whether SoP laws influence the equity-based portion of CEO pay by estimating the following regression specification:

$$
\begin{aligned}
& \frac{\text { Equity Pay }}{\text { Total Pay }}_{i t}=a^{\circ}+\beta^{*} \text { SoP }_{i t}+\gamma^{\circ * F_{i r m} \text { performance }} i t-1+\lambda^{*} \text { So }_{i t}{ }^{*} \text { Firm performance }_{i t-1}+\delta^{*} \text { firm } \\
& \text { controls }_{i t-1}+\eta^{\circ} *_{\text {country and industry controls }}+\theta_{i-1} * \text { CEO controls } s_{i t-1}+\mu^{*}{ }^{*} \text { year controls } s_{i-1}+\varepsilon^{\circ}{ }_{i t}
\end{aligned}
$$

\footnotetext{
12 Empirical evidence suggests limited shareholder activism exerted by public pension funds in the U.S. and abroad (e.g., Karpoff, Malatesta, and Walkling (1996) and Kotter and Lel (2011)).
} 
where the dependent variable is a measure of the CEO pay structure and equity-based pay includes both stock and options awards. The other variables are the same as those defined earlier for equation (1), and the specification also includes firm and year fixed effects.

Results from this equation are reported in Table 4. The first two columns show coefficient estimates for equity-based pay as a portion of total pay, and the next two columns use the natural logarithms of equity-based CEO pay and non-equity based CEO pay, respectively. Column (1) shows that the equity-based portion of total CEO pay decreases following the adoption of SoP laws (-0.06, $\mathrm{t}$ $=-5.57)$. In the next column, we estimate equation (2) using a Tobit estimator as a robustness check, as our dependent variable is bounded below 0 and 1 , and find similar effects. ${ }^{13}$ Given the abundant empirical evidence that risk taking incentives of managers are influenced by equity-based pay, the decrease in equity-based pay associated with SoP laws points to a potentially harmful consequence of these laws on shareholder value.

The final two columns further show that this decrease is a result of the numerator effect: It comes solely from declines in the equity-based component of pay while other forms of pay do not change. Thus, the previously documented effect of SoP laws on the level of CEO compensation in Table 2 is related to decreases in stock and option awards. This finding is similar to Ferri and Maber (2013), who document significant declines in performance-based vesting conditions in equity grants following the passage of SoP laws in the UK. Table 4 further shows that the performance sensitivity of both forms of CEO pay increases following the passage of SoP laws.

\section{SoP Laws and CEO Pay Slice}

\footnotetext{
13 In this column, we replace firm fixed effects with country and industry fixed effects at the 2-digit SIC level, and report the model's chi-squared value instead of R-squared.
} 
Do the effects of SoP laws extend beyond CEO pay policy and structure? This section tests a specific effect of SoP laws, the pay inequality among top managers. In particular, we examine if SoP laws influence the portion of total top management pay captured by the CEO, or CPS. The descriptive statistics in Panel B of Table 1 show that there is a large pay differential between the pay granted to the CEO and to next 4 senior executives with highest pay. The average CEO captures $47 \%$ of total pay of five executives with the highest pay. Several studies show that the CPS has been going up in the United States (e.g., Bebchuk and Grinstein (2005), Murphy and Zabojnik (2007)), and we also observe a similar positive trend for most countries in our sample.

Previous research shows that the pay gap amongst the CEO and other senior managers can be due to tournament incentives or CEO power. In the former group of studies, the pay gap is set by the board of directors to provide incentives to non-CEO executives to induce greater effort (e.g., Lazear and Rosen (1981)). In the latter group of studies, the dominant position of the CEO allows her to extract higher pay at the cost of shareholder wealth (e.g., Bebchuk et al. (2011)). Such pay gaps can also reflect relative value creation of the jobs of the CEO and other managers or the premium for talent. Several studies also provide evidence that such pay inequality among the senior management can influence firm value (Kale et al. (2009), Bebchuk et al. (2011), Burns et al. (2013)), which we analyze in the next section.

To analyze the potential effects of SoP laws on the managerial pay differentials, we estimate the following specification:

$$
\begin{aligned}
& \text { CEO Pay Slice } i t=a^{\prime}+\beta^{*} \text { SoP }_{i t}+\delta^{*} \text { firm controls }_{i t-1}+\eta^{*}{\text { country and industry controls } \text { it }-1+}^{+} \\
& \theta^{*} \text { CEO controlsit-1 }+\mu^{\prime *} \text { year controlsit-1 }+\varepsilon^{\prime}{ }_{i t}
\end{aligned}
$$


where CEO pay slice is defined as the portion of total annual compensation of the five highest-paid managers captured by the CEO. The specification also includes the same control variables as in equation (1) and several additional variables that are shown by prior studies to influence the pay differentials among top managers (namely the ratio of cash holdings to total assets and a dummy variable that represents if a non-U.S. firm's shares are traded in the U.S. stock exchanges).

These tests employ the pay on senior managers as a control sample in analyzing CEO pay. In this way, they are less subject to endogeneity concerns, as the firm effects on the level of CEO pay are perfectly controlled for and are akin to triple difference estimates. This estimator captures the impact of SoP laws on the difference between CEO compensation and other top managerial compensation before and after the SoP laws and between the countries with and without such laws. However, sample size in this type of tests decreases substantially, as we add the constraint that compensation information on at least two senior executives in addition to that on the CEO is available for each firm.

The results from estimating the regression specification in equation (3) are reported in Table 5. The first column shows that SoP laws are associated with lower CPS, as the coefficient on SoP is negative and statistically significant at the one percent level $(-0.010, t=-3.07)$. In the next column, we estimate equation (3) using Tobit as a robustness check, because our dependent variable is bounded between 0 and 1 , and find similar effects of SoP laws on the CEO pay slice. In the last column, we replace CPS with an alternative measure of the pay differential among the top managers. The pay gap is defined as the natural logarithm of the difference between CEO pay and the median value in total annual pay among the five highest-paid managers. This alternative estimation also shows that the CEO pay gap narrows following the passage of SoP laws in the subsample of countries that pass such laws. The coefficient on SoP is -0.142 and is highly statistically significant $(t=-5.05)$. In untabulated tests, we also find that the decrease in pay differential is explained by lower CEO pay with no significant 
change in median senior management pay, thereby making managerial pay more equal within the firm's management team. These findings point to an unintended consequence of SoP laws: The pay gap among executives shrinks following the passage of SoP laws, which provide shareholders with a stronger voice in executive compensation. In this way, our results are consistent with Bebchuk et al. (2011), who argue that a higher CPS can be an indicator of the degree to which the CEO extracts rents in the form of higher pay.

\section{SoP laws and Firm Valuation}

In this section we complement our analysis of the impact of SoP laws on executive compensation by testing whether SoP laws are associated with changes in firm value. SoP laws can increase firm value directly by reducing abnormal levels of CEO pay, linking CEO pay to firm performance more strongly, and shrinking the pay inequality among top managers, and indirectly through providing a greater dialogue between directors and shareholders. In settings where board nominations are influenced by the CEO (e.g., Bebchuk (2003), Shivdasani, and Yermack (1999)), SoP laws can empower boards to more effectively negotiate executive compensation terms using the SoP votes. However, corporate boards are likely to have better information on the qualities of the CEO and on the firm's needs, operating environment, and objectives. Further, SoP laws can lead to the homogenization of CEO pay packages, forcing boards of directors to adopt one-size-for-all suboptimal policies that are perceived as best practices by proxy advisors (e.g., Gordon (2008)). Thus, an alternative hypothesis is that any deviation from the optimal executive compensation policies due to shareholder pressure can reduce firm value.

We test these competing hypotheses by examining changes in firm value around the time SoP laws are adopted. We exclude firms in the financial and regulated industries because of their unique 
business structure. Table 6 shows results from these regressions where we use industry-adjusted Tobin's Q as our proxy for firm value. The first column reports a positive and statistically significant coefficient on the SoP law dummy $(0.036, \mathrm{t}=7.62)$, suggesting a $3.6 \%$ increase firm value following the adoption of SoP laws. This result is consistent with the findings of several studies on the valuation consequences of SoP laws in the United States. More specifically, in line with the positive firm valuation effects of SoP laws, Cai and Walking (2011) find that firm values increased within the three days surrounding the US House of Representatives' passage of SoP legislation in 2007, in cases when the CEOs had abnormally high compensation and a lower pay for performance sensitivity. Further, Cunat, Gine, and Guadalupe (2012) show that voluntary SoP proposals are associated with a 2.7\% increase in stock prices on the day they are passed.

The increased alignment of CEO pay to firm performance that we document in Table 2 is potentially one of the channels through which SoP laws increase firm value. The decrease in CEO pay, which could be value-increasing under the assumption that CEO pay prior to SoP laws was abnormal, is too small to justify the 3.6\% change in Tobin's Q alone. We hypothesize that the decrease in CPS can be an additional way for SoP laws to enhance firm value.

In particular, several studies show that higher pay differentials amongst senior managers are related to lower firm values (e.g., Siegel and Hambrick (2005), Bebchuck et al. (2011)). For example, Bebchuk et al. (2011) document a significant relation between a higher CPS and corporate outcomes, such as bad acquisition decisions and lower CEO turnover. However, the literature on tournament incentives suggests that reductions in the CEO pay gap can reduce firm value (e.g., Kale et al. (2009), Burns et al. (2013), Main, O’Reilly, and Wade (1993)). We test the valuation effects of the CEO pay gap using the staggered adoption of SoP laws across countries as a natural experiment.

The way we test this hypothesis is by identifying firms with relatively high levels of CPS in the 
pre-SoP period and to compare changes in firm value around SoP laws between this subsample of firms and the rest. Accordingly, we create an indicator variable, high CEO pay slice, that takes on the value of one for firms whose abnormal CEO pay slice values are greater than the country median values in the period prior to the enactment of SoP laws, and zero otherwise. Abnormal CEO pay slice values are defined as the difference between actual levels of pay slices and their estimated values obtained from fitting the regression specification in column (1) of Table 5.

Consistent with the first set of studies described above, the second column in Table 6 shows a positive and statistically significant coefficient on high CEO pay slice $(0.018, \mathrm{t}=2.08)$, suggesting that firms with higher levels of CPS prior to the SoP laws experience a larger increase in firm value following the enactment of the laws. Taken together with our previous finding that SoP laws reduce

CPS, these results imply that the increase in firm value is partly related to changes in CPS around the adoption of SoP laws, and that pay inequality among the top management team partially reflects management entrenchment.

\section{Robustness Tests}

\subsection{Say on Pay Laws as an Outcome of Political Environment and Sentiments}

In this section we examine the robustness of our results shown in previous tables on CEO pay, CEO pay structure, CEO pay slice, and firm value to potential endogeneity, omitted variables, and various subsamples. An important concern with our estimators is that SoP laws might be enacted because of recent changes in compensation levels and economic activity in the country. Thus, even when SoP laws have no influence on CEO compensation, our estimator might erroneously attribute differential changes in CEO pay between firms subject to SoP laws and the control group of firms to the passage of SoP laws. 
To overcome this concern, we instrument the passage of SoP laws using measures of the political and cultural environment in our sample of countries. These proxies capture the sentiment in the country toward pay differentials and the ability of the current government in power (i.e., voting power) and its leaning towards passing economic regulations. ${ }^{14}$ In general, political economy variables are shown to be linked to regulatory changes (e.g., Krozner and Strahan (1999)) and there is an increasing literature on the relationship between political choices in democracies and financial structures and outcomes across countries (e.g., Perotti (2013)). This instrumental approach helps us to distribute the likelihood of SoP law passage quasi-randomly across countries with similar political and cultural environments.

The results from this instrumental variable estimation with firm fixed effects are reported in Panel A of Table 7 . The sample size is smaller than in previous tables due to missing information on the political and cultural environment for some countries and years in the main sample. The first column in Panel A of Table 7 shows that when we instrument SoP laws with the current political and cultural environment of the country, we continue to find that SoP laws are associated with lower CEO pay levels and a greater link between firm performance and CEO pay. In the next three columns we also find that the effect of SoP laws on CEO pay structure, CEO pay slice and firm value is similar to the previously reported results. ${ }^{15}$ These findings suggest that our results are not exclusively driven by the

\footnotetext{
14 These variables are dummy variables that denote if the party orientation with respect to economic policy is right or left leaning, the largest opposition party's voting share, and the interaction terms between these political environment variables and the degree to which people in a society consider differences in income to be fair based on differences in more efficiency, reliability, and speed resulting in differences in pay. The political variables are obtained from the World Bank's database on Political Institutions 2012 (Beck et al. (2001)), and the cultural variable is obtained from the World Values Survey (http://www.worldvaluessurvey.org/). These variables are good instruments to the extent they influence the likelihood of SoP law passage and not proxy for the pre-law economic environment.

15 Our first-stage regressions show that countries are more likely to pass SoP laws when the political party in power is either right or left wing compared to other parties (right-leaning parties have a greater influence on this probability) but less so when the voters are more tolerant of income differences based on effort and talent differentials, and less likely to pass such laws when the main opposition party has a greater voting power (results untabulated). These variables are jointly different from zero ( $\mathrm{p}$-value for the Wald chi-square test < 0.01 ) suggesting that our instrumental variables satisfy the relevance condition. The under-identification test reported for each column at the bottom of Table 7 show that the Kleibergen-Paap (2006) LM test statistic is statistically significant, rejecting the null hypothesis that the coefficients of the excluded
} 
possibility that SoP laws are an outcome of recent changes in compensation levels and economic activity in the country.

We also undertake a test where we control for potentially omitted time-varying variables at the industry level and concurrent changes in laws across countries to ensure that our results are not driven by changes at the industry and country level in the post-law period. We do so by introducing industry*year fixed effects into the regression specification and by excluding two countries (United States and Netherlands) that approved additional laws that can directly affect compensation policies at the same time as SoP laws. ${ }^{16}$ Panel B of Table 7 shows that our results are robust to controlling for potentially omitted time-varying variables that can subsume the documented effects of SoP laws on our key variables of interest in the post-law period. Our results also survive regressions where we include the year prior to the adoption of SoP laws as an indicator variable and its interaction term with firm performance to control for the pre-law environment, and where we include the current firm performance and its interaction term with SoP law dummy in the last two columns of Table 2 in the Appendix.

\subsection{Additional Robustness Tests}

instruments are jointly equal to zero. Our instrumental variables are also not weakly related to the passage of SoP laws as shown by statistically significant Kleibergen-Paap (2006) weak identification test statistics. Finally, the Sargan-Hansen over-identification test is not statistically significant for columns (1) and (3), suggesting that our instruments are valid. However, a caveat with the instrumental variable analysis is that for our instruments do not satisfy the exclusion condition for columns (2) and (4).

16 The Dodd-Frank Act of 2010, which defines the current SoP framework in the United States, also mandates an independent compensation committee for listed firms and requires the disclosure of executive compensation through proxy statements before annual meetings. In the Netherlands, changes to Book 2 of the Dutch Civil Code, which introduced the SoP laws, also give rights to shareholders holding 1\% of share capital to submit items to the agenda of the annual shareholders meeting, which was given the right to appoint and dismiss supervisory board members for the first time. We do not exclude other countries that passed some non-compensation related provisions around the time SoP laws are enacted. For example, the SoP law is passed in Australia with a package that also includes enhancements of auditor independence. 
We also examine the robustness of our results to various subsamples and report the results in Table 8. Due to space concerns, we only report coefficient estimates on SoP and the interaction term between SoP and firm performance in this table. As control variables, each row includes all the independent variables in the regression specification reported in column (4) of Table 2 for CEO pay and CEO pay structure, and column (1) in Table 5 for CEO pay slice, and column (1) in Table 6 for firm value.

We recognize that not all countries mandate their firms to disclose CEO pay, and this cross-country variation in disclosure regulations can create a potential selection bias in our tests. Thus, in our first robustness check, we limit our sample to countries with such a mandate. The information on mandated disclosure regulations is obtained from Fernandes et al. (2013). There are 14 such countries in our sample. We report the results on our main tests in Panel A, which shows a similar effect of SoP laws on CEO pay policies, CEO pay slice and firm value to the previously reported results. To ensure our results are not driven by such a reporting bias, we also run regressions after including a dummy variable to denote the mandatory compensation disclosure regulations in our main tests and continue to find that our main results hold (untabulated).

We next test the robustness of our results to excluding U.S. firms, which make up $31 \%$ of our sample. Results from these regressions are reported in Panel B, which again report similar results. In Panel $\mathrm{C}$ we exclude firms that experience a turnover of the $\mathrm{CEO}$ in the year of enactment of the SoP law, as the compensation package for the incumbent and new CEOs can be unusual. In the next panel, we report results where we re-run our previously reported estimations without firms in the financial and regulated industries (2-digit SIC codes of 60-69 and 49), as such firms are heavily regulated and some financial institutions have been subject to additional regulatory scrutiny during the recent global crisis. 


\section{Binding versus Advisory SoP Laws}

While 12 countries have passed SoP laws to date, the content of such laws differ substantially across countries. The most important difference in SoP laws, in terms of the criticism received by shareholders and the public, is whether the board of directors has to address shareholder disapproval on executive pay (binding SoP votes) or not (advisory SoP laws), even though companies are required in both cases to put the compensation policy up for voting on a periodical basis. ${ }^{17}$

The inability of shareholders to force the firm to change their executive compensation plans following failed SoP votes has led to shareholder lawsuits and some shareholders to threaten the re-election of members in the compensation committees at firms that have not taken corrective action following failed SoP votes. ${ }^{18}$ Further, the UK is currently planning to make its advisory SoP laws mandatory, and the European Commissioner Michel Barnier has recently proposed that the European Union members adopt binding SoP laws. However, there is no evidence on whether the binding or advisory SoP laws provide the best response to compensation related problems.

In this section, we provide the first empirical comparison between binding and advisory SoP laws in terms of their effect on CEO pay, CEO pay structure, CEO pay slice, and firm value. For these tests, we replace the SoP dummy with the binding and advisory SoP law dummy variables and re-estimate our relevant specifications in the previous tables. The results from these estimations are reported in Table 9.

\footnotetext{
17 The SoP laws also differ based on the stated objective (whether the objective is the CEO pay policy or pay structure) and the frequency of the voting on executive compensation (whether it is to be held annually or not). All countries that have binding SoP laws allow shareholders to vote on the CEO pay policy with the exception of Israel and Portugal, and all countries with advisory SoP laws except for Switzerland allow shareholders to vote on the CEO pay structure. The correlation between the presence of binding (advisory) SoP laws and SoP laws on CEO pay policy (pay structure) is 98.6\% (99.1\%). Thus, it is empirically not possible to disentangle the effects of binding versus advisory SoP laws from the SoP laws on pay policy versus pay structure. Similarly, most countries explicitly require that the shareholder voting on executive compensation to be held on an annual basis.

18 See "Calpers to awaken zombie boards," Dan McCrum, Financial Times, April 7, 2013.
} 
In the first two columns, we examine the impact of binding and advisory SoP laws on CEO compensation using industry-adjusted stock returns and ROA to proxy for firm financial performance, respectively. The results show that binding SoP laws have at best minimal effect on the level of CEO pay as reported by the negative and marginally significant coefficient on binding SoP in column (1) and insignificant coefficient on this variable in column (2) $(-0.048, \mathrm{t}=-1.69$ and $-0.045, \mathrm{t}=$ -1.62 , respectively). These columns also show that there is no effect of binding SoP laws on the sensitivity of CEO pay to firm performance. However, the level of CEO pay is significantly lower in the case of advisory SoP laws. For example, the coefficient on advisory SoP is -0.054, which is significant at the one-percent level. This type of laws are also associated with a greater alignment of pay to firm performance as shown by a positive coefficient on the interaction terms between advisory SoP law and firm performance. Thus, advisory laws have an effect on executive compensation that is consistent with two of the main objectives of SoP laws.

In the third column we find that both types of SoP laws reduce the equity-based component of total CEO pay but the magnitude is about 6 times greater for binding SoP laws. When we analyze the levels of equity and non-equity based components, we observe that binding laws have about 8 times as much negative effect on the level of equity-based pay as advisory laws do, and only the former class of laws is associated with higher non-equity based pay. Table 9 further shows that the CEO pay slice decreases only when advisory laws are passed, as shown by the negative and significant coefficient on advisory SoP law in column (4). The final two columns report that firm value measured by the industry-adjusted natural logarithm of Tobin's Q is higher by similar amounts in case of the passage of both binding and advisory SoP laws. Firms with relatively higher levels of CPS in the pre-SoP period 
experience a larger increase in firm value only in the case of advisory SoP laws. ${ }^{19}$

Overall, results in Table 9 suggest that mandatory SoP laws are not more effective than advisory ones in their effect on CEO compensation. Indeed, we find that advisory SoP laws are overall more influential on CEO compensation policies. While both types of laws improve firm value, only advisory SoP laws tighten the link between firm pay and performance, reduce total CEO pay levels and the CPS. Given that we further find that firm value is higher for firms that had high CPS relative to other firms in the country prior to the enactment of these laws, we conclude that average firms do not benefit from mandatory SoP laws more than advisory ones.

\section{Conclusion}

In this paper, we examine changes in CEO compensation policies, the CEO pay slice, and firm value after say on pay laws are adopted using a cross-country sample. Our analysis provides four novel findings. First, the level of CEO pay is lower in the period following the adoption of SoP laws, which stems from declines in equity-based pay. The growth in estimated CEO pay is lower for firms subject to SoP laws compared to the control group of firms in the pre-law period and to firms located in countries that never pass such laws. Further, the link between CEO pay and firm performance becomes stronger after the passage of SoP laws. Moreover, SoP laws have greater effects on CEO compensation policies in firms with more powerful CEOs, where CEO power is measured by board busyness and CEO tenure. These results are consistent with the stated objectives of SoP laws.

Second, the pay gap between the CEO and other top executives shrinks after SoP laws are

\footnotetext{
19 Australia's government adopted legislation strengthening its say-on-pay requirements in July 2011. It introduced the two-strikes test, which provides shareholders with the opportunity to remove directors if the company's compensation report had received a 'no' vote of $25 \%$ or more at two consecutive annual general meetings. It also prohibited directors and executives from voting on executive pay. Our results are robust to controlling for this change in the Australian SoP laws in our main regressions (where we include a dummy variable that denotes Australian firms in the post-2010 period).
} 
passed. Third, firm value increases for firm located in countries that adopt SoP laws in the post-law period, and this increase is linked to the incidence of high CEO pay slice in the pre-SoP period. The effect of SoP laws on the managerial pay gap and subsequently on firm value point to an unintentional outcome of these laws. Finally, binding SoP laws have much weaker effects on CEO compensation policies than advisory laws. In fact, only advisory SoP laws are associated with a tighter relation between pay and performance. Overall, our results suggest that SoP laws have had substantial effects on compensation policies and firm value. 


\section{References}

Aggarwal, R., I. Erel, M. Ferreira, P. Matos, 2011. Does governance travel around the world? Evidence from institutional investors. Journal of Financial Economics 100, 154-181.

Adams, R.B., B. Hermalin, and M. S. Weisbach, 2010. The role of boards of directors in corporate governance: A conceptual framework and survey, Journal of Economic Literature 48, 58-107.

Alissa, W. 2009, Boards' response to shareholders' dissatisfaction: The case of shareholders' say on pay in the UK. Available at SSRN: http://ssrn.com/abstract=1412880.

Bainbridge, S.M., 2008. Remarks on say on pay: an unjustified incursion on director authority. UCLA School of Law, Law-Econ Research Paper No. 08-06.

Bainbridge, S.M., 2011. Dodd-Frank: quack federal corporate governance round II, 95 Minn. L. Rev. 1779-1815.

Balsam, S., E. Gordon, X. Li, and E. Runesson, 2013, Mandatory disclosure reform and executive compensation: Is CFO pay higher after the mandatory adoption of IFRS? working paper.

Bebchuk, L.A., J. Fried, and D. Walker. 2002. Managerial power and rent extraction in the design of executive compensation, University of Chicago Law Review 69, 751-846.

Bebchuk, L. A., 2003, The case for shareholder access to the ballot. Business Lawyer 59, 43-66.

Bebchuk, L. A., and J. Fried, 2003, Executive compensation as an agency problem, Journal of Economic Perspectives 17, 71-92.

Bebchuk, L. A., and J. Fried, 2005, Pay without performance: Overview of the issues, Journal of Applied Corporate Finance 17, 8-23.

Bebchuk, L.A., Y. Grinstein, 2005, The growth of executive pay, Oxford review of economic policy 21, 283-303.

Bebchuk, L., M. Cremers, and U. Peyer, 2011, The CEO pay slice. Journal of Financial Economics 102, 199-221.

Bebchuk, L. A., A. Friedman, and W. Friedman, 2007, Empowering shareholders on executive compensation: hearing on H.R. 1257 before the H. Comm. on Fin. Servs., 110th Cong. 68 available at http://www.gpo.gov/fdsys/pkg/CHRG-110hhrg35402/pdf/CHRG-110hhrg35402.pdf.

Beck, T., G. Clarke, A. Groff, P. Keefer, and P. Walsh, 2001, New tools in comparative political economy: The Database of political institutions. World Bank Economic Review 15, 165-176.

Boone, A., L. Field, J. Karpoff, and R. Charu. 2007. The determinants of corporate board size and composition: An empirical analysis, Journal of Financial Economics 85, 66-101 
Bryan, S., R. Nash, and A. Patel, 2010. How legal system affects the equity mix in executive compensation, Financial Management 1, 393-418.

Burns, N., K. Minnick, and L. Starks, 2013, CEO tournaments: A cross-country analysis of causes, cultural influences and consequences, Available at SSRN: http://ssrn.com/abstract=2261788.

Cai, J., R. Walkling, 2011. Shareholders' say on pay: does it create value? Journal of Finance and Quantitative Analysis 46, 299-339.

Cai, J., J. Garner, and R. Walkling, 2009, Electing directors, Journal of Finance 64, 2389-2421.

Coates, J., 2009. Examining the improvement of corporate governance for the protection of shareholders and the enhancement of public confidence. Hearing before the Subcommittee on Securities, Insurance and Investment of the Committee on Banking, Housing and Urban Affairs, US Senate $111^{\text {th }}$ Congress, July 29, 2009 (http://www.access.gpo.gov/congress/senate/senate05sh.html)

Coles, J., N. Daniel, and L. Naveen, 2007, Co-opted board: Costs, benefits, causes, and consequences, Working paper, Arizona State University.

Core, J.E., Guay, W.R., Larcker, D.F., 2003. Executive equity compensation and incentives: a survey. Economic Policy Review 9, 1-25.

Core, J., R. Holthausen, and D. Larcker, 1999. Corporate governance, chief executive officer compensation, and firm performance. Journal of Financial Economics 51, 371-406.

Cuñat, V., M. Gine, and M. Guadalupe, 2013, Say pays! Shareholder voice and firm performance, Upjohn Institute Working Paper No. 13-192.

Dahya, J., O. Dimitrov, and J. McConnell, 2008, Dominant Shareholders, Corporate Boards and Corporate Value: A Cross-Country Analysis, Journal of Financial Economics 8, 73-100.

Davis, S. 2007, Does 'say on pay' work? Lessons on making CEO compensation accountable, Yale Millstein Center Policy Briefing.

Ertimur, Y., Ferri, F., Muslu, V., 2011. Shareholder activism and CEO pay. Review of Financial Studies 24, 535-592.

Fernandes, N., M. A. Ferreira, P. Matos, and K. J. Murphy, 2013, Are US CEOs paid more? New international evidence, Review of Financial Studies 26, 323-367.

Ferri, F., and M. Maber, 2013. Say on pay votes and CEO compensation: evidence from the UK. Review of Finance 17, 527-563.

Ferris, S., M. Jagannathan, and A. Pritchard. 2003. Too busy to mind the business? Monitoring by directors with multiple board appointments, Journal of Finance 58, 1087-1111.

Fich, E. and A. Shivdasani. 2006. Are busy boards effective monitors, Journal of Finance 61, 689-721. 
Gordon, J., 2009. "Say on pay": cautionary notes on the U.K. experience and the case for shareholder opt-in. Harvard Journal on Legislation 46, 323-341.

Grundfest, J, 1993, Just vote no: A minimalist strategy for dealing with barbarians inside the gates, Stanford Law Review 45, 857-937.

Hartzell, J., L. Starks, 2003. Institutional investors and executive compensation, Journal of Finance 58, 2351-2374.

Holmstrom, B., 1979, Moral hazard and observability, Bell Journal of Economics 10, 74-91.

Iliev, P., Lins, K., Miller, D., and Roth, L., 2012. Shareholder voting and corporate governance around the world. Working paper.

Iliev, P. and S. Vitanova, 2013, The effect of say-on-pay in the U.S., working paper.

Kale, J., E. Reis, and A. Venkateswaran, 2009. Rank-order tournaments and incentive alignment: The effect on firm performance. Journal of Finance 64, 1479-1512.

Kaplan, S., 2007. Empowering shareholders on executive compensation: hearing on H.R. 1257 before the H.Comm. on Fin. Servs., 110th Cong. 126 available at http://www.gpo.gov/fdsys/pkg/CHRG-110hhrg35402/pdf/CHRG-110hhrg35402.pdf.

Karpoff, J., Malatesta, P., Walkling, R., 1996. Corporate governance and shareholder initiatives: empirical evidence. Journal of Financial Economics 42, 365-295.

Kotter, J. and Lel, U., 2011. Friends or foes? Target selection decisions of sovereign wealth funds and their consequences. Journal of Financial Economics 101, 360-381.

Kimbro, M. and D. Xu, 2013, Shareholders have a say on executive compensation: Evidence from say-on-pay in the United States, Available at SSRN: http://ssrn.com/abstract=2209936.

Kroszner, R. S. and P. E. Strahan, 1999, What drives deregulation? Economics and politics of the relaxation of bank branching restrictions. The Quarterly Journal of Economics 114, 1437-1467.

Lazear, E. and S. Rosen, 1981, Rank-order tournaments as optimum labor contracts, Journal of Political Economy 89, 841-864.

Larcker, D.F., G. Ormazabal, D. Taylor, 2011. The market reaction to corporate governance regulation. Journal of Financial Economics 101, 431-448.

Larcker, D.F., B. Tayan, 2012a. Union activism: do union pension funds act solely in the interest of beneficiaries? Rock Center for Corporate Governance at Stanford University Closer Look Series: Topics, Issues and Controversies in Corporate Governance and Leadership No. CGRP- 30.

Larcker, D. F., A. McCall, G. Ormazabal, B. Tayan, 2012b, Ten myths of 'say on pay'. Rock Center for Corporate Governance at Stanford University Closer Look Series: Topics, Issues and Controversies in Corporate Governance No. CGRP-26. 
Lel, U. and D. Miller, 2008, International cross-listing, firm performance and top management turnover: a test of the bonding hypothesis, Journal of Finance 63, 1897-1937.

Main, B., C. O'Reilly, and J. Wade, 1993. Top executive pay: Tournament or teamwork?, Journal of Labor Economics 11, 606-628.

McCahery, J., Z. Sautner, and L. Starks. 2012. Behind the scenes: The corporate governance preferences of institutional investors. Working Paper. University of Amsterdam.

Murphy, K.. J., 2013, Executive compensation: Where we are, and how we got there. in George Constantinides, Milton Harris, and René Stulz (eds.), Handbook of the Economics of Finance. Elsevier Science North Holland (forthcoming)

Murphy, K. J. and J. Zabojnik, 2007, Managerial capital and the market for CEOs. Available at SSRN: http:/ / ssrn.com/abstract $=984376$.

Ozkan, N., Z. Singer, and H. You, 2013. Mandatory IFRS adoption and the contractual usefulness of accounting information in executive compensation. Journal of Accounting Research (forthcoming).

Perotti, E., 2013, The political economy of finance. Tinbergen Institute Discussion Papers 13-034/ IV/DSF53, Tinbergen Institute.

Romanchek, Bob and Tony Meyer, 2013. Say on Pay Lawsuits: History, Analysis and Future Direction. https://www.boardmember.com/Say-on-Pay-Lawsuits-History-Analysis-and-Future-Direction.aspx

Ryan, H., and R. Wiggins, 2004. Who is in whose pocket? Director compensation, board independence, and barriers to effective monitoring. Journal of Financial Economics 73, 497-524.

Shivdasani, A. and D. Yermack. 1999. CEO involvement in the selection of new board members: An empirical analysis, Journal of Finance 54, 1829-1853.

Siegel, P. and D. Hambrick, 2005, Pay disparities within top management groups: Evidence of harmful effects on performance of high-technology firms, Organization Science 16, 259-274.

Yermack, David. 1996. Higher market valuation of companies with a small board of directors. Journal of Financial Economics 40, 185-211.

Yermack, David. 2010. Shareholder voting and corporate governance. Annual Review of Financial Economics 2, 103-125. 


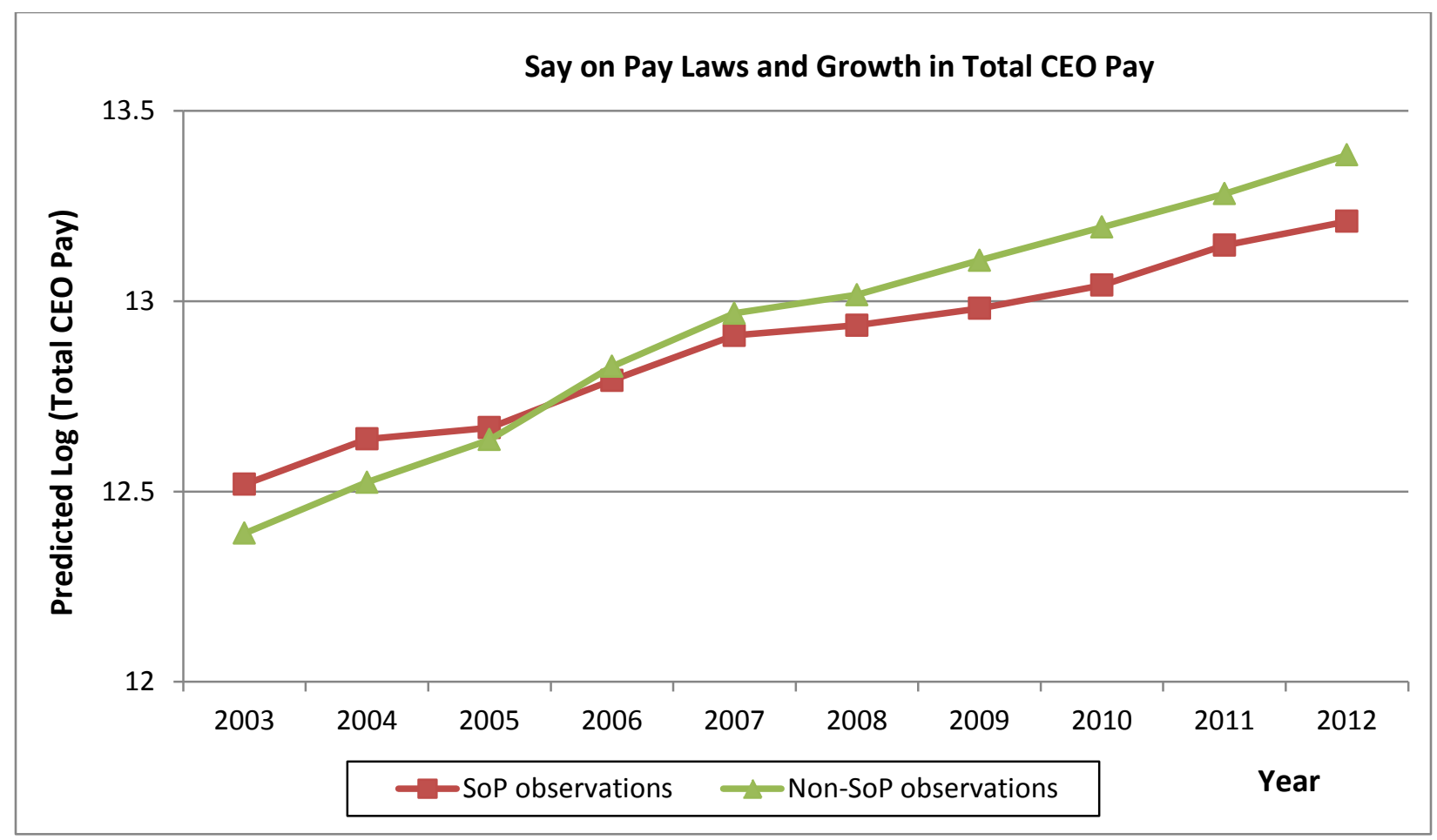

Figure 1. This figure shows the estimated average CEO pay over time for SoP and non-SoP observations for a firm with $\$ 1$ billion in sales and average values of other variables based on the regression specification in column (4) of Table 2. SoP observations include firms in countries that eventually pass a SoP law for the post-law period. The rest of the sample constitutes the non-SoP observations group. The starting year is 2003 because the first year for the SoP subsample is 2002. 


\section{Table 1. Descriptive Statistics}

This table presents the distribution of the regression sample by country and descriptive statistics for the main variables. Panel A displays the number of observations, firms, and mean values for total CEO compensation, the ratio of equity-based pay to total CEO pay, and CEO pay slice across countries. In column (4) under the heading of SoP law year, (A) refers to advisory SoP laws and (B) refers to binding SoP laws. Panel B shows univariate statistics for the sample used in the analysis. Table A1 in the Appendix provides variable definitions and data sources. We winsorize all continuous variables at the one percent level and use one-year lagged values of time-varying independent variables.

Panel A. Sample Distribution by Country

\begin{tabular}{|c|c|c|c|c|c|c|c|}
\hline Country & \# Obs. & \# Firms & $\begin{array}{c}\text { SoP } \\
\text { Law Year }\end{array}$ & Country & \# Obs. & \# Firms & $\begin{array}{c}\text { SoP } \\
\text { Law Year }\end{array}$ \\
\hline Australia & 11,070 & 2,037 & $2005(\mathrm{~A})$ & Jordan & 48 & 16 & - \\
\hline Austria & 111 & 26 & - & Luxembourg & 74 & 17 & - \\
\hline Belgium & 272 & 74 & $2012(\mathrm{~A})$ & Malaysia & 497 & 133 & - \\
\hline Bermuda & 218 & 50 & - & Netherlands & 1,063 & 176 & 2004 (B) \\
\hline Canada & 14,731 & 2,861 & - & New Zealand & 385 & 104 & - \\
\hline Chile & 77 & 20 & - & Norway & 893 & 198 & 2007 (B) \\
\hline China & 1,727 & 495 & - & Oman & 127 & 33 & - \\
\hline Denmark & 135 & 36 & 2007 (B) & Pakistan & 376 & 146 & - \\
\hline Finland & 483 & 113 & - & Philippines & 149 & 37 & - \\
\hline France & 1,664 & 323 & - & Poland & 222 & 69 & - \\
\hline Germany & 1,832 & 412 & - & Portugal & 91 & 34 & 2009 (A) \\
\hline Greece & 33 & 15 & - & Singapore & 318 & 85 & - \\
\hline Hong Kong & 6,577 & 1,037 & - & South Africa & 2,193 & 386 & 2011 (B) \\
\hline Iceland & 57 & 15 & - & Spain & 219 & 52 & - \\
\hline India & 8,584 & 1,913 & - & Sweden & 1,145 & 246 & 2006 (B) \\
\hline Ireland & 482 & 84 & - & Switzerland & 931 & 232 & 2013 (B) \\
\hline Israel & 222 & 65 & 2013 (A) & Taiwan & 100 & 45 & - \\
\hline Italy & 1,143 & 283 & - & Thailand & 929 & 229 & - \\
\hline \multirow[t]{2}{*}{ Japan } & 90 & 58 & - & United Kingdom & 11,396 & 2,197 & $2003(\mathrm{~A})$ \\
\hline & & & & United States & 32,675 & 5,999 & $2011(\mathrm{~A})$ \\
\hline Total & 103,339 & 20,351 & & & & & \\
\hline
\end{tabular}


Panel B. Firm, CEO, and country characteristics

\begin{tabular}{lcccc}
\hline Variables & $\#$ Obs & Mean & Median & Standard deviation \\
\hline Total CEO pay & 103,339 & $1,241,054$ & 388,632 & $9,420,137$ \\
Equity CEO pay / total CEO pay & 103,213 & 0.095 & 0.000 & 0.205 \\
CEO pay slice & 64,624 & 0.470 & 0.440 & 0.201 \\
Pay gap & 64,040 & 805,040 & 237,173 & $1,660,330$ \\
High CEO pay slice & 103,339 & 0.177 & 0.000 & 0.382 \\
Industry-adjusted stock returns & 103,339 & 0.194 & 0.005 & 0.956 \\
Industry-adjusted ROA & 102,878 & -0.106 & 0.002 & 0.789 \\
Industry-adjusted log (Q) & 101,770 & 0.112 & -0.001 & 0.464 \\
Annualized stock return volatility & 98,010 & 0.058 & 0.058 & 0.020 \\
Net sales (\$US millions) & 103,339 & 1,230 & 71.8 & 4,190 \\
Total assets (\$US millions) & 103,245 & 3,060 & 133 & 12,800 \\
Leverage & 103,054 & 0.139 & 0.055 & 0.197 \\
Cash / total assets & 103,339 & 0.087 & 0.021 & 0.153 \\
Capex / total assets & 103,339 & 0.489 & 0.220 & 0.755 \\
Inside ownership (\%) & 103,339 & 0.299 & 0.251 & 0.271 \\
Total institutional ownership (\%) & 100,150 & 0.121 & 0.003 & 0.213 \\
Independent director \% & 96,121 & 0.574 & 0.600 & 0.248 \\
Board size & 100,819 & 7.081 & 7.000 & 4.301 \\
Dual CEO dummy & 103,339 & 0.130 & 0.000 & 0.336 \\
Number of directorships & 103,339 & 1.213 & 1.000 & 0.826 \\
Average board directorship & 100,631 & 2.087 & 1.800 & 1.083 \\
CEO tenure & 51,617 & 8.208 & 6.000 & 8.122 \\
Grey institutional ownership (\%) & 100,150 & 0.110 & 0.000 & 0.421 \\
Independent institutional ownership (\%) & 100,150 & 0.119 & 0.003 & 0.210 \\
ADR dummy & 103,339 & 0.078 & 0.000 & 0.268 \\
Industry mkbk ratio & 103,334 & 1.590 & 1.485 & 0.535 \\
GDP growth (\%) & 103,326 & 2.679 & 2.607 & 2.991 \\
Inflation rate (\%) & 103,152 & 3.046 & 2.811 & 2.193 \\
\hline
\end{tabular}




\section{Table 2. Say on Pay Laws and Total CEO Compensation}

This table presents estimates of the impact of SoP laws on the level of CEO pay and the sensitivity of CEO pay to firm performance. The dependent variable is the natural logarithm of total annual CEO compensation (total CEO pay). Table A1 in the Appendix provides variable definitions and data sources. We winsorize all continuous variables at the one percent level and use one-year lagged values of time-varying independent variables. The t-statistics appear in brackets below parameter estimates. Robust standard errors are estimated by clustering at the firm level. Asterisks ***, **, and * indicate significance at the $1 \%, 5 \%$, and $10 \%$ level, respectively.

Firm performance is industry-adjusted stock returns

\section{Firm performance is industry-adjusted \\ ROA}

\begin{tabular}{|c|c|c|c|c|c|}
\hline Variables & (1) & (2) & (3) & (4) & (5) \\
\hline SoP & $\begin{array}{c}-0.063 * * * \\
{[-5.426]}\end{array}$ & $\begin{array}{c}-0.061 * * * \\
{[-5.210]}\end{array}$ & $\begin{array}{c}-0.049 * * * \\
{[-4.064]}\end{array}$ & $\begin{array}{c}-0.055^{* * *} \\
{[-4.471]}\end{array}$ & $\begin{array}{c}-0.052^{* * *} \\
{[-4.297]}\end{array}$ \\
\hline Firm performance & $\begin{array}{c}0.030^{* * *} \\
{[10.798]}\end{array}$ & $\begin{array}{l}0.033 * * * \\
{[11.571]}\end{array}$ & $\begin{array}{c}0.033 * * * \\
{[11.166]}\end{array}$ & $\begin{array}{c}0.033 * * * \\
{[10.977]}\end{array}$ & $\begin{array}{c}0.035^{* * * *} \\
{[6.467]}\end{array}$ \\
\hline SoP $*$ Firm performance & $\begin{array}{c}0.054 * * * \\
{[8.589]}\end{array}$ & $\begin{array}{c}0.050^{* * *} \\
{[7.833]}\end{array}$ & $\begin{array}{c}0.049 * * * \\
{[7.600]}\end{array}$ & $\begin{array}{c}0.049 * * * \\
{[7.524]}\end{array}$ & $\begin{array}{c}0.029 * * \\
{[2.350]}\end{array}$ \\
\hline Log (net sales) & $\begin{array}{l}0.020^{* * *} \\
{[18.422]}\end{array}$ & $\begin{array}{c}0.019 * * * \\
{[17.247]}\end{array}$ & $\begin{array}{c}0.018^{* * *} \\
{[16.363]}\end{array}$ & $\begin{array}{l}0.018^{* * *} \\
{[16.097]}\end{array}$ & $\begin{array}{l}0.017 * * * \\
{[15.303]}\end{array}$ \\
\hline Leverage & - & $\begin{array}{c}-0.01 \\
{[-0.475]}\end{array}$ & $\begin{array}{l}-0.009 \\
{[-0.415]}\end{array}$ & $\begin{array}{c}-0.033 \\
{[-1.469]}\end{array}$ & $\begin{array}{c}-0.014 \\
{[-0.646]}\end{array}$ \\
\hline Stock return volatility & - & $\begin{array}{l}-2.659 * * * \\
{[-11.723]}\end{array}$ & $\begin{array}{c}-2.586 * * * \\
{[-11.162]}\end{array}$ & $\begin{array}{c}-2.577 * * * \\
{[-10.840]}\end{array}$ & $\begin{array}{c}-2.128^{* * *} \\
{[-9.364]}\end{array}$ \\
\hline Inside ownership (\%) & - & - & $\begin{array}{c}-0.049 * * * \\
{[-2.851]}\end{array}$ & $\begin{array}{c}-0.046 * * * \\
{[-2.618]}\end{array}$ & $\begin{array}{l}-0.044 * * \\
{[-2.576]}\end{array}$ \\
\hline Total institutional ownership (\%) & - & - & $\begin{array}{l}0.200 * * * \\
{[10.467]}\end{array}$ & $\begin{array}{c}0.193 * * * \\
{[10.020]}\end{array}$ & $\begin{array}{l}0.202^{* * *} \\
{[10.712]}\end{array}$ \\
\hline Independent director $\%$ & - & - & - & $\begin{array}{c}0.064 * * * \\
{[3.062]}\end{array}$ & $\begin{array}{c}0.072^{* * * *} \\
{[3.484]}\end{array}$ \\
\hline Board size & - & - & - & $\begin{array}{c}0.010^{* * * *} \\
{[7.331]}\end{array}$ & $\begin{array}{c}0.011 * * * \\
{[7.759]}\end{array}$ \\
\hline Dual CEO dummy & - & - & - & $\begin{array}{c}-0.034 * * * \\
{[-3.038]}\end{array}$ & $\begin{array}{c}-0.030^{* * * *} \\
{[-2.707]}\end{array}$ \\
\hline $\log$ (number of directorships) & - & - & - & $\begin{array}{c}0.054 * * * \\
{[3.416]}\end{array}$ & $\begin{array}{c}0.054 * * * \\
{[3.498]}\end{array}$ \\
\hline Industry mkbk ratio & - & $\begin{array}{l}-0.022^{*} \\
{[-1.687]}\end{array}$ & $\begin{array}{c}-0.019 \\
{[-1.475]}\end{array}$ & $\begin{array}{c}-0.027^{* *} \\
{[-2.003]}\end{array}$ & $\begin{array}{c}-0.037 * * * * \\
{[-2.761]}\end{array}$ \\
\hline GDP growth & - & $\begin{array}{c}0.012^{* * *} \\
{[6.137]}\end{array}$ & $\begin{array}{c}0.012^{* * *} \\
{[6.407]}\end{array}$ & $\begin{array}{c}0.012^{* * * *} \\
{[6.355]}\end{array}$ & $\begin{array}{c}0.014 * * * \\
{[7.430]}\end{array}$ \\
\hline Inflation & - & $\begin{array}{c}0.005^{* * *} \\
{[2.639]}\end{array}$ & $\begin{array}{c}0.005^{* *} \\
{[2.543]}\end{array}$ & $\begin{array}{l}0.005^{* *} \\
{[2.487]}\end{array}$ & $\begin{array}{c}0.006^{* * *} \\
{[2.706]}\end{array}$ \\
\hline Constant & $\begin{array}{l}12.945^{* * *} \\
{[477.513]}\end{array}$ & $\begin{array}{l}13.057 * * * \\
{[370.782]}\end{array}$ & $\begin{array}{l}13.024 * * * \\
{[360.694]}\end{array}$ & $\begin{array}{l}12.928^{* * *} \\
{[319.235]}\end{array}$ & $\begin{array}{l}12.927 * * * \\
{[327.420]}\end{array}$ \\
\hline $\begin{array}{l}\text { Firm F.E. } \\
\text { Year F.E. }\end{array}$ & $\begin{array}{l}\text { Yes } \\
\text { Yes }\end{array}$ & $\begin{array}{l}\text { Yes } \\
\text { Yes }\end{array}$ & $\begin{array}{l}\text { Yes } \\
\text { Yes }\end{array}$ & $\begin{array}{l}\text { Yes } \\
\text { Yes }\end{array}$ & $\begin{array}{l}\text { Yes } \\
\text { Yes }\end{array}$ \\
\hline $\begin{array}{l}\text { Observations } \\
\text { R-squared } \\
\text { Number of firms }\end{array}$ & $\begin{array}{c}103,339 \\
0.147 \\
20,351\end{array}$ & $\begin{array}{c}97,553 \\
0.149 \\
19,037\end{array}$ & $\begin{array}{c}94,752 \\
0.15 \\
18,830\end{array}$ & $\begin{array}{c}89,056 \\
0.155 \\
17,584\end{array}$ & $\begin{array}{c}92,925 \\
0.152 \\
18,251\end{array}$ \\
\hline
\end{tabular}


Table 3. Say on Pay Laws and Total CEO Compensation: CEO Power and Monitoring Intensity

This table presents estimates of the relation between the strength of corporate governance and the impact of SoP laws on the level of CEO pay and the sensitivity of CEO pay to firm performance. The dependent variable is the natural logarithm of total annual CEO compensation (total CEO pay). Each row represents results from a regression specification that includes all the independent variables in the regression specification in column (4) of Table 2 as control variables. Table A1 in the Appendix provides variable definitions and data sources. We winsorize all continuous variables at the one percent level and use one-year lagged values of time-varying independent variables. The t-statistics appear in brackets below parameter estimates. Robust standard errors are estimated by clustering at the firm level. Asterisks ***, **, and * indicate significance at the $1 \%, 5 \%$, and $10 \%$ level, respectively.

\begin{tabular}{|c|c|c|c|c|}
\hline $\begin{array}{c}\text { Average } \\
\text { board } \\
\text { directorship }\end{array}$ & $\begin{array}{l}\text { CEO } \\
\text { tenure }\end{array}$ & $\begin{array}{c}\text { Independent } \\
\text { director } \%\end{array}$ & $\begin{array}{c}\text { Grey } \\
\text { Institutional } \\
\text { ownership \% }\end{array}$ & $\begin{array}{l}\text { Independent } \\
\text { Institutional } \\
\text { ownership \% }\end{array}$ \\
\hline (1) & $(2)$ & (3) & (4) & (5) \\
\hline $\begin{array}{c}-0.021 \\
{[-0.928]}\end{array}$ & $\begin{array}{c}0.003 \\
{[0.137]}\end{array}$ & $\begin{array}{c}-0.102 * * * \\
{[-3.146]}\end{array}$ & $\begin{array}{c}-0.047 * * * \\
{[-3.727]}\end{array}$ & $\begin{array}{c}-0.047^{* * *} \\
{[-3.539]}\end{array}$ \\
\hline 0.010 & $0.029 * *$ & $0.034^{* *}$ & $0.048^{* * *}$ & $0.047 * * *$ \\
\hline [0.691] & [2.493] & {$[2.026]$} & [7.299] & [6.535] \\
\hline$-0.015^{*}$ & $-0.003^{* *}$ & 0.078 & $-0.043^{*}$ & -0.054 \\
\hline [-1.682] & [-2.481] & [1.576] & [-1.921] & [-1.366] \\
\hline $0.018^{* * *}$ & -0.001 & 0.028 & $0.063^{* *}$ & 0.024 \\
\hline$[3.064]$ & {$[-0.865]$} & [1.079] & {$[2.305]$} & {$[0.624]$} \\
\hline$-0.011 *$ & $0.003^{* * *}$ & 0.043 & $0.080^{* * *}$ & $0.205^{* * *}$ \\
\hline$[-1.707]$ & {$[2.635]$} & [1.295] & {$[9.790]$} & {$[9.552]$} \\
\hline $0.033^{* * *}$ & $0.038^{* * *}$ & $0.033^{* * *}$ & $0.033 * * *$ & $0.033^{* * *}$ \\
\hline [10.951] & {$[8.743]$} & [9.510] & [11.013] & [10.964] \\
\hline Yes & Yes & Yes & Yes & Yes \\
\hline Yes & Yes & Yes & Yes & Yes \\
\hline Yes & Yes & Yes & Yes & Yes \\
\hline Yes & Yes & Yes & Yes & Yes \\
\hline 88,880 & 45,952 & 89,056 & 89,056 & 89,056 \\
\hline 0.155 & 0.159 & 0.155 & 0.155 & 0.155 \\
\hline
\end{tabular}


Table 4. Say on Pay Laws and CEO Compensation Structure

This table presents estimates of the impact of SoP laws on the CEO pay structure. The dependent variable is the portion of CEO pay coming from the equity-based component in columns (1) and (2), the natural logarithm of the equity-based CEO pay in column (3), and the natural logarithm of non-equity based CEO pay in column (4). Firm fixed effects along with year dummy variables are used in the estimations. Table A1 in the Appendix provides variable definitions and data sources. We winsorize all continuous variables at the one percent level and use one-year lagged values of time-varying independent variables. The t-statistics appear in brackets below parameter estimates. Robust standard errors are estimated by clustering at the firm level. Asterisks ***,**, and * indicate significance at the $1 \%, 5 \%$, and $10 \%$ level, respectively.

\begin{tabular}{|c|c|c|c|c|}
\hline & \\
\hline & $\begin{array}{c}\text { Equity pay / } \\
\text { CEO pay } \\
\text { (Firm F.E.) }\end{array}$ & $\begin{array}{c}\text { Equity pay / } \\
\text { CEO pay } \\
\text { (Tobit) }\end{array}$ & $\begin{array}{c}\text { Log } \\
\text { (equity-based } \\
\text { CEO pay) }\end{array}$ & $\begin{array}{l}\text { Log (non-equity } \\
\text { based CEO pay) }\end{array}$ \\
\hline Variables & (1) & $(2)$ & (3) & (4) \\
\hline \multirow[t]{2}{*}{ SoP } & $-0.060 * * *$ & $-0.022 * * *$ & $-0.524 * * *$ & 0.02 \\
\hline & {$[-5.571]$} & {$[-7.907]$} & {$[-7.429]$} & [0.985] \\
\hline \multirow[t]{2}{*}{ Firm performance } & $0.012^{* * *}$ & $0.001 * *$ & -0.021 & $0.027 * * *$ \\
\hline & [4.759] & [1.991] & {$[-1.205]$} & [5.379] \\
\hline \multirow[t]{2}{*}{ SoP $*$ Firm performance } & $0.030 * * *$ & $0.011 * * *$ & $0.283^{* * *}$ & $0.035^{* * *}$ \\
\hline & {$[6.202]$} & [7.095] & {$[7.521]$} & {$[3.267]$} \\
\hline \multirow[t]{2}{*}{ Log (net sales) } & $0.001 * * *$ & $0.001 * *$ & $0.022^{* * *}$ & $0.019^{* * *}$ \\
\hline & [2.603] & {$[2.061]$} & [3.393] & {$[10.567]$} \\
\hline \multirow[t]{2}{*}{ Leverage } & $0.090^{* * *}$ & -0.002 & -0.01 & -0.03 \\
\hline & [8.187] & {$[-0.396]$} & {$[-0.075]$} & {$[-0.835]$} \\
\hline \multirow[t]{2}{*}{ Stock return volatility } & $-0.682^{* * *}$ & $-0.485^{* * *}$ & $-7.817 * * *$ & $-2.487 * * *$ \\
\hline & {$[-4.914]$} & {$[-8.920]$} & {$[-5.683]$} & {$[-6.433]$} \\
\hline \multirow[t]{2}{*}{ Inside ownership (\%) } & $-0.156^{* * *}$ & $-0.027 * * *$ & $-0.849 * * *$ & 0.032 \\
\hline & {$[-17.220]$} & {$[-6.615]$} & {$[-8.281]$} & [1.108] \\
\hline \multirow[t]{2}{*}{ Total institutional ownership (\%) } & $0.278^{* * *}$ & $0.013 * * *$ & $0.711 * * *$ & $0.192 * * *$ \\
\hline & [29.862] & {$[2.977]$} & [6.382] & [6.133] \\
\hline \multirow[t]{2}{*}{ Independent director $\%$} & $0.117 * * *$ & 0.004 & $0.233^{*}$ & 0.035 \\
\hline & [12.414] & {$[0.894]$} & [1.919] & [1.023] \\
\hline \multirow[t]{2}{*}{ Board size } & $0.016^{* * *}$ & $0.003^{* * *}$ & $0.083^{* * *}$ & $-0.004^{*}$ \\
\hline & [25.528] & {$[10.280]$} & [10.068] & {$[-1.884]$} \\
\hline \multirow[t]{2}{*}{ Dual CEO dummy } & $0.011^{*}$ & 0.002 & $0.107^{*}$ & $-0.117 * * *$ \\
\hline & [1.771] & [0.878] & [1.649] & [-6.397] \\
\hline \multirow[t]{2}{*}{ Log (number of directorships) } & -0.014 & 0.001 & -0.118 & $-0.276 * * *$ \\
\hline & {$[-1.323]$} & {$[0.230]$} & {$[-1.318]$} & {$[-10.996]$} \\
\hline \multirow[t]{2}{*}{ Industry mkbk ratio } & $-0.030 * *$ & $-0.015^{* * *}$ & $-0.574 * * *$ & -0.007 \\
\hline & {$[-2.523]$} & [-4.695] & [-7.329] & {$[-0.322]$} \\
\hline \multirow[t]{2}{*}{ GDP growth } & $0.007 * * *$ & $0.002 * * *$ & $0.081 * * *$ & $0.008^{* *}$ \\
\hline & [3.571] & [5.024] & [7.165] & {$[2.375]$} \\
\hline \multirow[t]{2}{*}{ Inflation } & $-0.016 * * *$ & $-0.007 * * *$ & $-0.207 * * *$ & $0.020^{* * *}$ \\
\hline & {$[-8.373]$} & {$[-13.793]$} & {$[-17.119]$} & [5.927] \\
\hline \multirow[t]{2}{*}{ Constant } & $-0.166^{* * *}$ & $0.174 * * *$ & $5.578^{* * *}$ & $12.666^{* * *}$ \\
\hline & {$[-3.722]$} & {$[18.734]$} & {$[23.802]$} & {$[192.280]$} \\
\hline Firm F.E. & Yes & No & Yes & Yes \\
\hline Year F.E. & Yes & Yes & Yes & Yes \\
\hline Country F.E. & No & Yes & No & No \\
\hline Industry F.E. (2-digit SIC) & No & Yes & No & No \\
\hline Observations & 88,939 & 88,939 & 89,363 & 89,490 \\
\hline R-squared ( $X^{2}$ statistic) & 0.111 & $31,144 * * *$ & 0.181 & 0.042 \\
\hline
\end{tabular}


Table 5. Say on Pay Laws and CEO Pay Slice

This table presents estimates of the impact of SoP laws on CEO pay slice. The dependent variable is the portion of total annual compensation of the top five highest-paid managers captured by the CEO in the first two columns and the difference between CEO pay and the median value in total annual pay among the top five managers in the last column. The first and last columns report OLS estimates with firm and year fixed effects, and column (2) provides Tobit estimates with country, industry, and year fixed effects. Table A1 in the Appendix provides variable definitions and data sources. We winsorize all continuous variables at the one percent level and use one-year lagged values of time-varying independent variables. The t-statistics appear in brackets below parameter estimates. Robust standard errors are estimated by clustering at the firm level. Asterisks $* * *, * *$, and $*$ indicate significance at the $1 \%, 5 \%$, and $10 \%$ level, respectively.

\begin{tabular}{|c|c|c|}
\hline $\begin{array}{c}\text { CEO pay slice } \\
\text { (Firm F.E.) }\end{array}$ & $\begin{array}{c}\text { CEO pay slice } \\
\text { (Tobit) }\end{array}$ & $\begin{array}{c}\text { Log } \\
\text { (CEO pay gap) }\end{array}$ \\
\hline (1) & (2) & (3) \\
\hline$-0.010 * * *$ & $-0.016^{* * *}$ & $-0.142^{* * *}$ \\
\hline [-3.069] & [-3.990] & {$[-5.052]$} \\
\hline$-0.002 * * *$ & $-0.004 * * *$ & $0.021 * * *$ \\
\hline$[-7.614]$ & [-19.822] & [7.372] \\
\hline-0.006 & 0.002 & $-0.159 * * *$ \\
\hline [-0.991] & [0.556] & {$[-2.970]$} \\
\hline$-0.194 * * *$ & $-0.379 * * *$ & $-2.599 * * *$ \\
\hline$[-2.996]$ & {$[-6.964]$} & {$[-4.587]$} \\
\hline 0.003 & $-0.027 * * *$ & $-0.110^{* *}$ \\
\hline$[0.420]$ & [-5.009] & [-2.018] \\
\hline 0.0004 & 0.001 & $0.039 * * *$ \\
\hline [0.291] & [0.793] & [3.044] \\
\hline-0.0003 & $-0.014 * * *$ & -0.062 \\
\hline$[-0.050]$ & {$[-4.378]$} & {$[-1.286]$} \\
\hline 0.004 & $-0.013^{* * *}$ & $-0.129 * * *$ \\
\hline$[0.808]$ & {$[-3.767]$} & {$[-3.056]$} \\
\hline$-0.024 * * *$ & $-0.024 * * *$ & $0.098^{* *}$ \\
\hline$[-5.034]$ & {$[-6.246]$} & [2.453] \\
\hline $0.082^{* * *}$ & $0.072^{* * *}$ & $0.146^{* * *}$ \\
\hline [13.276] & [19.026] & [2.707] \\
\hline$-0.007 * * *$ & $-0.006^{* * *}$ & $0.013^{* * *}$ \\
\hline$[-15.934]$ & {$[-21.958]$} & [3.512] \\
\hline$-0.012^{* * *}$ & $-0.005^{* *}$ & $-0.071 * * *$ \\
\hline [-3.739] & {$[-2.167]$} & {$[-2.636]$} \\
\hline-0.002 & 0.003 & 0.042 \\
\hline$[-0.495]$ & [0.800] & [1.038] \\
\hline 0.004 & 0.005 & $-0.056^{*}$ \\
\hline [0.992] & [1.172] & [-1.818] \\
\hline-0.001 & -0.0003 & $0.012^{* *}$ \\
\hline$[-1.244\rceil]$ & {$[-0.387\rceil$} & $\lceil 2.259\rceil$ \\
\hline$-0.002^{* *}$ & $-0.001 *$ & $-0.012^{* *}$ \\
\hline$[-2.509]$ & {$[-1.936]$} & {$[-2.285]$} \\
\hline $\begin{array}{c}0.517 * * * \\
{[45.320]}\end{array}$ & $\begin{array}{c}0.578 * * * \\
{[35.397]}\end{array}$ & $\begin{array}{l}12.700 * * * \\
{[127.322]}\end{array}$ \\
\hline Yes & No & Yes \\
\hline Yes & Yes & Yes \\
\hline No & Yes & No \\
\hline No & Yes & No \\
\hline 56,896 & 56,896 & 50,645 \\
\hline 0.02 & $7,470 * * *$ & 0.104 \\
\hline
\end{tabular}


Table 6. Firm Valuation, Say on Pay Laws, and CEO Pay Slice

This table presents estimates of the impact of SoP laws and the CEO pay slice on firm value and risk. The dependent variable is the industry-adjusted natural logarithm of Tobin's Q. Financial and regulated utility industries are excluded. Firm and year fixed effects are included in all columns. Table A1 in the Appendix provides variable definitions and data sources. We winsorize all continuous variables at the one percent level and use one-year lagged values of time-varying independent variables. The t-statistics appear in brackets below parameter estimates. Robust standard errors are estimated by clustering at the firm level. Asterisks ***, $* *$, and $*$ indicate significance at the $1 \%, 5 \%$, and $10 \%$ level, respectively.

\begin{tabular}{|c|c|c|}
\hline \multirow[b]{2}{*}{ Variables } & \multicolumn{2}{|c|}{ Industry-adjusted $\log (\mathrm{Q})$} \\
\hline & (1) & $(2)$ \\
\hline SoP & $\begin{array}{c}0.036^{* * *} \\
{[7.616]}\end{array}$ & $\begin{array}{c}0.030 * * * \\
{[5.218]}\end{array}$ \\
\hline SoP $*$ High CEO pay slice & - & $\begin{array}{c}0.018^{* *} \\
{[2.081]}\end{array}$ \\
\hline Log (assets) & $\begin{array}{c}-0.099 * * * \\
{[-57.530]}\end{array}$ & $\begin{array}{c}-0.099 * * * \\
{[-57.529]}\end{array}$ \\
\hline Leverage & $\begin{array}{c}0.087^{* * *} \\
{[9.999]}\end{array}$ & $\begin{array}{c}0.087 * * * \\
{[10.005]}\end{array}$ \\
\hline Stock return volatility & $\begin{array}{c}0.631 * * * \\
{[7.093]}\end{array}$ & $\begin{array}{c}0.633^{* * *} \\
{[7.113]}\end{array}$ \\
\hline Cash / total assets & $\begin{array}{c}0.092^{* * *} \\
{[10.550]}\end{array}$ & $\begin{array}{c}0.091 * * * \\
{[10.525]}\end{array}$ \\
\hline Industry-adjusted ROA & $\begin{array}{c}-0.003 \\
{[-1.310]}\end{array}$ & $\begin{array}{c}-0.003 \\
{[-1.308]}\end{array}$ \\
\hline ADR dummy & $\begin{array}{c}0.026 * * * \\
{[3.330]}\end{array}$ & $\begin{array}{c}0.027 * * * \\
{[3.337]}\end{array}$ \\
\hline Capex / total assets & $\begin{array}{c}0.003 \\
{[1.561]}\end{array}$ & $\begin{array}{c}0.003 \\
{[1.547]}\end{array}$ \\
\hline Inside ownership (\%) & $\begin{array}{c}0.012 \\
{[0.668]}\end{array}$ & $\begin{array}{c}0.012 \\
{[0.692]}\end{array}$ \\
\hline Inside ownership squared (\%) & $\begin{array}{c}0.023 \\
{[1.059]}\end{array}$ & $\begin{array}{c}0.022 \\
{[1.035]}\end{array}$ \\
\hline Total institutional ownership (\%) & $\begin{array}{c}0.040 * * * \\
{[5.355]}\end{array}$ & $\begin{array}{c}0.040 * * * \\
{[5.419]}\end{array}$ \\
\hline Independent director $\%$ & $\begin{array}{c}-0.042^{* * *} \\
{[-5.306]}\end{array}$ & $\begin{array}{c}-0.043 * * * \\
{[-5.342]}\end{array}$ \\
\hline Board size & $\begin{array}{c}0.003^{* * *} \\
{[4.596]}\end{array}$ & $\begin{array}{c}0.003^{* * *} \\
{[4.602]}\end{array}$ \\
\hline Dual CEO dummy & $\begin{array}{c}0.010 * * \\
{[2.439]}\end{array}$ & $\begin{array}{c}0.010^{* *} \\
{[2.444]}\end{array}$ \\
\hline GDP growth & $\begin{array}{c}0.001 * \\
{[1.922]}\end{array}$ & $\begin{array}{c}0.001 * \\
{[1.898]}\end{array}$ \\
\hline Inflation & $\begin{array}{c}0.016^{* * *} \\
{[19.592]}\end{array}$ & $\begin{array}{c}0.016^{* * *} \\
{[19.604]}\end{array}$ \\
\hline Constant & $\begin{array}{c}2.862 * * * \\
{[73.442]}\end{array}$ & $\begin{array}{c}2.862^{* * *} \\
{[73.459]}\end{array}$ \\
\hline $\begin{array}{l}\text { Firm F.E. } \\
\text { Year F.E. }\end{array}$ & $\begin{array}{l}\text { Yes } \\
\text { Yes }\end{array}$ & $\begin{array}{l}\text { Yes } \\
\text { Yes }\end{array}$ \\
\hline $\begin{array}{l}\text { Observations } \\
\text { R-squared }\end{array}$ & $\begin{array}{c}84,260 \\
0.138\end{array}$ & $\begin{array}{c}84,260 \\
0.138\end{array}$ \\
\hline
\end{tabular}




\section{Table 7. Potential Endogeneity, Concurrent Laws, and Time-varying Industry Factors}

This table presents estimates from robustness tests on the impact of SoP laws on CEO pay, CEO pay structure, CEO pay slice, and firm value. In Panel A, we report results from an instrumental variable firm fixed effect specification where the instrumental variables for the passage of SoP laws are dummy variables that denote if the party orientation with respect to economic policy is right or left leaning, the largest opposition party's voting share, and the interaction terms between these political environment variables and the degree to which people in a society consider differences in income to be fair based differences in more efficiency, reliability, and speed resulting in differences in pay. Panel B reports results from a regression specification that excludes two countries (United States and Netherlands) that passed compensation-related laws concurrent to SoP laws, and includes industry*year fixed effects to fully control for time-varying industry factors. Table A1 in the Appendix provides variable definitions and data sources. We winsorize all continuous variables at the one percent level and use one-year lagged values of time-varying independent variables. The t-statistics appear in brackets below

parameter estimates. Robust standard errors are estimated by clustering at the firm level. Asterisks ***, **, and * indicate significance at the $1 \%, 5 \%$, and $10 \%$ level, respectively. 
Panel A. Instrumenting SoP Laws

\begin{tabular}{|c|c|c|c|c|}
\hline & Log (CEO pay) & $\begin{array}{c}\text { Equity pay / } \\
\text { CEO pay } \\
\end{array}$ & CEO pay slice & $\begin{array}{c}\text { Industry-adjusted } \\
\log (Q) \\
\end{array}$ \\
\hline Variables & (1) & $(2)$ & (3) & $(4)$ \\
\hline SoP & $\begin{array}{c}-0.573 * * * \\
{[-5.049]}\end{array}$ & $\begin{array}{c}-0.407 * * * \\
{[-13.287]}\end{array}$ & $\begin{array}{c}-0.064 * * \\
{[-2.027]}\end{array}$ & $\begin{array}{c}0.290^{* * *} \\
{[6.961]}\end{array}$ \\
\hline Firm performance & $\begin{array}{c}0.029 * * * \\
{[6.848]}\end{array}$ & $\begin{array}{c}0.001 \\
{[0.800]}\end{array}$ & - & - \\
\hline SoP $*$ Firm performance & $\begin{array}{c}0.056^{* * *} \\
{[6.532]}\end{array}$ & $\begin{array}{c}0.018^{* * *} \\
{[7.438]}\end{array}$ & - & - \\
\hline Log (net sales) & $\begin{array}{c}0.016^{* * *} \\
{[7.766]}\end{array}$ & $\begin{array}{l}0.0003 \\
{[0.647]}\end{array}$ & $\begin{array}{c}-0.002^{* * *} \\
{[-5.009]}\end{array}$ & - \\
\hline Leverage & $\begin{array}{c}0.021 \\
{[0.521]}\end{array}$ & $\begin{array}{l}0.019 * * \\
{[2.367]}\end{array}$ & $\begin{array}{c}-0.001 \\
{[-0.146]}\end{array}$ & $\begin{array}{c}0.065^{* * *} \\
{[3.972]}\end{array}$ \\
\hline Stock return volatility & $\begin{array}{l}-0.681 * \\
{[-1.760]}\end{array}$ & $\begin{array}{c}0.066 \\
{[0.738]}\end{array}$ & $\begin{array}{c}-0.036 \\
{[-0.368]}\end{array}$ & $\begin{array}{c}0.195 \\
{[1.470]}\end{array}$ \\
\hline Inside ownership (\%) & $\begin{array}{c}-0.075^{* * *} \\
{[-2.696]}\end{array}$ & $\begin{array}{c}-0.029 * * * \\
{[-4.486]}\end{array}$ & $\begin{array}{c}0.012 \\
{[1.620]}\end{array}$ & $\begin{array}{c}0.01 \\
{[0.393]}\end{array}$ \\
\hline Total institutional ownership ( $\%)$ & $\begin{array}{c}0.366^{* * * *} \\
{[9.841]}\end{array}$ & $\begin{array}{c}0.061 * * * \\
{[6.315]}\end{array}$ & $\begin{array}{c}-0.012 \\
{[-1.456]}\end{array}$ & $\begin{array}{c}0.064 * * * \\
{[5.104]}\end{array}$ \\
\hline Independent director $\%$ & $\begin{array}{c}0.05 \\
{[1.216]}\end{array}$ & $\begin{array}{l}-0.014^{*} \\
{[-1.808]}\end{array}$ & $\begin{array}{c}0.096^{* * *} \\
{[8.658]}\end{array}$ & $\begin{array}{c}-0.027 * * \\
{[-2.132]}\end{array}$ \\
\hline Board size & $\begin{array}{c}0.010^{* * *} \\
{[3.335]}\end{array}$ & $\begin{array}{c}0.002^{* * *} \\
{[4.200]}\end{array}$ & $\begin{array}{c}-0.009 * * * \\
{[-11.153]}\end{array}$ & $\begin{array}{c}0.004^{* * *} \\
{[4.451]}\end{array}$ \\
\hline Dual CEO dummy & $\begin{array}{c}-0.050 * * \\
{[-2.438]}\end{array}$ & $\begin{array}{l}-0.0003 \\
{[-0.077]}\end{array}$ & $\begin{array}{c}-0.019 * * * \\
{[-3.911]}\end{array}$ & $\begin{array}{c}0.014 * * \\
{[2.066]}\end{array}$ \\
\hline Log (number of directorships) & $\begin{array}{l}0.052^{*} \\
{[1.869]}\end{array}$ & $\begin{array}{c}0.008 \\
{[1.594]}\end{array}$ & $\begin{array}{c}-0.001 \\
{[-0.123]}\end{array}$ & - \\
\hline Industry mkbk ratio & $\begin{array}{l}-0.021 \\
{[-1.026]}\end{array}$ & $\begin{array}{c}0.001 \\
{[0.236]}\end{array}$ & $\begin{array}{l}0.013 * * \\
{[2.355]}\end{array}$ & - \\
\hline GDP growth & $0.016^{* * *}$ & $0.002^{* * *}$ & -0.001 & $0.003^{* * *}$ \\
\hline Inflation & $\begin{array}{c}{[5.923]} \\
-0.005 \\
{[-1.581]}\end{array}$ & $\begin{array}{c}{[3.755]} \\
-0.007 * * * \\
{[-8.312]}\end{array}$ & $\begin{array}{c}{[-1.421]} \\
-0.001 \\
{[-1.534]}\end{array}$ & $\begin{array}{c}\lceil 3.661\rceil \\
0.014 * * * \\
{[14.561]}\end{array}$ \\
\hline Cash / total assets & - & - & $\begin{array}{c}0.004 \\
{[0.470]}\end{array}$ & $\begin{array}{c}0.089 * * * \\
{[5.118]}\end{array}$ \\
\hline Industry-adjusted ROA & - & - & $\begin{array}{c}-0.001 \\
{[-0.205]}\end{array}$ & $\begin{array}{c}0.002 \\
{[0.273]}\end{array}$ \\
\hline ADR dummy & - & - & $\begin{array}{l}0.020^{*} \\
{[1.918]}\end{array}$ & $\begin{array}{l}-0.008 \\
{[-0.790]}\end{array}$ \\
\hline Log (total assets) & - & - & - & $\begin{array}{l}-0.096 * * * \\
{[-25.870]}\end{array}$ \\
\hline Inside ownership squared (\%) & - & - & - & $\begin{array}{c}0.026 \\
{[0.854]}\end{array}$ \\
\hline Capex / total assets & - & - & - & $\begin{array}{l}0.005^{*} \\
{[1.718]}\end{array}$ \\
\hline $\begin{array}{l}\text { Firm F.E. } \\
\text { Year F.E. }\end{array}$ & $\begin{array}{l}\text { Yes } \\
\text { Yes }\end{array}$ & $\begin{array}{l}\text { Yes } \\
\text { Yes }\end{array}$ & $\begin{array}{l}\text { Yes } \\
\text { Yes }\end{array}$ & $\begin{array}{l}\text { Yes } \\
\text { Yes }\end{array}$ \\
\hline $\begin{array}{l}\text { Under-identification test } \\
\text { Weak identification test } \\
\text { Over-identification test }\end{array}$ & $\begin{array}{c}822.731 * * * \\
149.956 * * * \\
7.407\end{array}$ & $\begin{array}{c}821.841^{* * * *} \\
149.847^{* * *} * \\
80.631 * * *\end{array}$ & $\begin{array}{c}478.408^{* * * *} \\
176.85^{* * * * * *} \\
3.521\end{array}$ & $\begin{array}{c}792.157^{* * * *} \\
174.818^{* * *} * \\
42.049 * * *\end{array}$ \\
\hline $\begin{array}{l}\text { Observations } \\
\text { R-squared }\end{array}$ & $\begin{array}{c}74,156 \\
0.111 \\
\end{array}$ & $\begin{array}{r}74,066 \\
-0.155 \\
\end{array}$ & $\begin{array}{c}46,565 \\
0.027\end{array}$ & $\begin{array}{c}70,491 \\
0.112 \\
\end{array}$ \\
\hline
\end{tabular}


Panel B. Concurrent Laws and Time-varying Industry Factors

\begin{tabular}{|c|c|c|c|c|}
\hline & Log (CEO pay) & $\begin{array}{c}\text { Equity pay / } \\
\text { CEO pay }\end{array}$ & CEO pay slice & $\begin{array}{c}\text { Industry-adjusted } \\
\log (Q)\end{array}$ \\
\hline Variables & (1) & $(2)$ & (3) & $(4)$ \\
\hline SoP & $\begin{array}{c}-0.072^{* * *} \\
{[-4.211]}\end{array}$ & $\begin{array}{c}-0.018^{* * * *} \\
{[-5.497]}\end{array}$ & $\begin{array}{c}-0.027 * * * \\
{[-5.125]}\end{array}$ & $\begin{array}{c}0.061 * * * \\
{[9.768]}\end{array}$ \\
\hline Firm performance & $\begin{array}{c}0.035^{* * *} \\
{[9.252]}\end{array}$ & $\begin{array}{c}0.002^{* * *} \\
{[3.340]}\end{array}$ & - & - \\
\hline SoP $*$ Firm performance & $\begin{array}{c}0.042^{* * *} \\
{[5.830]}\end{array}$ & $\begin{array}{c}0.008^{* * *} \\
{[5.720]}\end{array}$ & - & - \\
\hline Log (net sales) & $\begin{array}{c}0.015^{* * *} \\
{[11.556]}\end{array}$ & $\begin{array}{l}-0.0001 \\
{[-0.788]}\end{array}$ & $\begin{array}{c}-0.002 * * * \\
{[-6.103]}\end{array}$ & - \\
\hline Leverage & $\begin{array}{c}0.012 \\
{[0.412]}\end{array}$ & $\begin{array}{c}0.004 \\
{[0.611]}\end{array}$ & $\begin{array}{c}0.002 \\
{[0.192]}\end{array}$ & $\begin{array}{c}0.072 * * * \\
{[6.679]}\end{array}$ \\
\hline Stock return volatility & $\begin{array}{c}-1.052 * * * \\
{[-3.471]}\end{array}$ & $\begin{array}{c}0.167 * * * \\
{[2.807]}\end{array}$ & $\begin{array}{c}0.013 \\
{[0.142]}\end{array}$ & $\begin{array}{c}0.045 \\
{[0.424]}\end{array}$ \\
\hline Inside ownership (\%) & $\begin{array}{c}-0.017 \\
{[-0.765]}\end{array}$ & $\begin{array}{l}-0.008^{*} \\
{[-1.873]}\end{array}$ & $\begin{array}{l}0.014 * * \\
{[2.018]}\end{array}$ & $\begin{array}{c}0.003 \\
{[0.139]}\end{array}$ \\
\hline Total institutional ownership (\%) & $\begin{array}{c}0.448^{* * *} \\
{[13.535]}\end{array}$ & $\begin{array}{c}0.066^{* * *} \\
{[10.094]}\end{array}$ & $\begin{array}{c}-0.015 \\
{[-1.621]}\end{array}$ & $\begin{array}{c}0.054 * * * \\
{[4.474]}\end{array}$ \\
\hline Independent director $\%$ & $\begin{array}{c}0.029 \\
{[1.095]}\end{array}$ & $\begin{array}{c}-0.005 \\
{[-0.979]}\end{array}$ & $\begin{array}{l}0.109 * * * \\
{[11.911]}\end{array}$ & $\begin{array}{c}-0.031 * * * \\
{[-3.312]}\end{array}$ \\
\hline Board size & $\begin{array}{c}0.009 * * * \\
{[5.788]}\end{array}$ & $\begin{array}{c}0.003^{* * *} \\
{[9.036]}\end{array}$ & $\begin{array}{l}-0.009 * * * \\
{[-17.035]}\end{array}$ & $\begin{array}{c}0.003^{* * *} \\
{[4.274]}\end{array}$ \\
\hline Dual CEO dummy & $\begin{array}{c}-0.061 * * * \\
{[-4.137]}\end{array}$ & $\begin{array}{c}0.001 \\
{[0.418]}\end{array}$ & $\begin{array}{c}-0.024 * * * \\
{[-5.370]}\end{array}$ & $\begin{array}{c}0.016^{* * *} \\
{[3.040]}\end{array}$ \\
\hline Log (number of directorships) & $\begin{array}{c}0.064 * * * \\
{[3.720]}\end{array}$ & $\begin{array}{c}-0.001 \\
{[-0.421]}\end{array}$ & $\begin{array}{c}-0.002 \\
{[-0.382]}\end{array}$ & - \\
\hline Industry mkbk ratio & $\begin{array}{c}0.063 \\
{[0.537]}\end{array}$ & $\begin{array}{c}-0.019 \\
{[-0.849]}\end{array}$ & $\begin{array}{c}0.014 \\
{[0.456]}\end{array}$ & - \\
\hline GDP growth & $\begin{array}{c}0.011 * * * \\
\lceil 5.028\rceil\end{array}$ & $\begin{array}{c}0.002^{* * *} \\
\lceil 4.213\rceil\end{array}$ & $\begin{array}{c}-0.00006 \\
{[-0.381\rceil}\end{array}$ & $\begin{array}{c}0.003^{* * *} \\
\lceil 3.433\rceil\end{array}$ \\
\hline Inflation & $\begin{array}{c}0.005^{* *} \\
{[2.174]}\end{array}$ & $\begin{array}{c}-0.004^{* * *} \\
{[-7.635]}\end{array}$ & $\begin{array}{c}-0.001 \\
{[-1.375]}\end{array}$ & $\begin{array}{c}0.011 * * * \\
{[13.102]}\end{array}$ \\
\hline Cash / total assets & - & - & $\begin{array}{c}0.001 \\
{[0.158]}\end{array}$ & $\begin{array}{c}0.109^{* * *} \\
{[11.193]}\end{array}$ \\
\hline Industry-adjusted ROA & - & - & $\begin{array}{l}-0.0001 \\
{[-0.162]}\end{array}$ & $\begin{array}{l}-0.004 \\
{[-1.387]}\end{array}$ \\
\hline ADR dummy & - & - & $\begin{array}{c}0.009 \\
{[1.502]}\end{array}$ & $\begin{array}{l}0.008 \\
{[1.075]}\end{array}$ \\
\hline Log (total assets) & - & - & - & $\begin{array}{c}-0.090 * * * \\
{[-45.911]}\end{array}$ \\
\hline Inside ownership squared $(\%)$ & - & - & - & $\begin{array}{c}0.021 \\
{[0.854]}\end{array}$ \\
\hline Capex / total assets & - & - & - & $\begin{array}{c}0.003 \\
{[1.629]}\end{array}$ \\
\hline Constant & $\begin{array}{c}11.431 * * * \\
{[64.287]}\end{array}$ & $\begin{array}{c}-0.013 \\
{[-0.382]}\end{array}$ & $\begin{array}{c}0.576^{* * *} \\
{[11.359]}\end{array}$ & $\begin{array}{c}2.552 * * * \\
{[55.202]}\end{array}$ \\
\hline $\begin{array}{l}\text { Firm F.E. } \\
\text { Year F.E. } \\
\text { Industry*Year F.E. }\end{array}$ & $\begin{array}{c}\text { Yes } \\
\text { Yes } \\
\text { Yes }\end{array}$ & $\begin{array}{l}\text { Yes } \\
\text { Yes } \\
\text { Yes }\end{array}$ & $\begin{array}{l}\text { Yes } \\
\text { Yes } \\
\text { Yes }\end{array}$ & $\begin{array}{l}\text { Yes } \\
\text { Yes } \\
\text { Yes }\end{array}$ \\
\hline $\begin{array}{l}\text { Observations } \\
\text { R-squared }\end{array}$ & $\begin{array}{c}64,799 \\
0.141\end{array}$ & $\begin{array}{c}64,682 \\
0.079\end{array}$ & $\begin{array}{c}37,221 \\
0.049\end{array}$ & $\begin{array}{c}61,545 \\
0.158\end{array}$ \\
\hline
\end{tabular}


Table 8. Robustness

This table presents firm fixed effect estimates of the impact of SoP laws on CEO pay, CEO pay structure, CEO pay slice, and firm value under different subsamples. As control variables, each row includes all the independent variables in the regression specification reported in column (4) of Table 2 for CEO pay and CEO pay structure, and column (1) in Table 5 for CEO pay slice, and column (1) in Table 6 for firm value. Panel B reports results for the subsample of countries that mandate the disclosure of CEO pay, panel B excludes U.S. firms, panel C excludes firms that experience a turnover of the CEO in the year of the turnover, and panel D excludes financial institutions and regulated utilities (2-digit sic codes = 60-69, 49). Table $A 1$ in the Appendix provides variable definitions and data sources. We winsorize all continuous variables at the one percent level and use one-year lagged values of time-varying independent variables. The t-statistics appear in brackets below parameter estimates. Robust standard errors are estimated by clustering at the firm level. Asterisks ***, **, and * indicate significance at the $1 \%, 5 \%$, and $10 \%$ level, respectively.

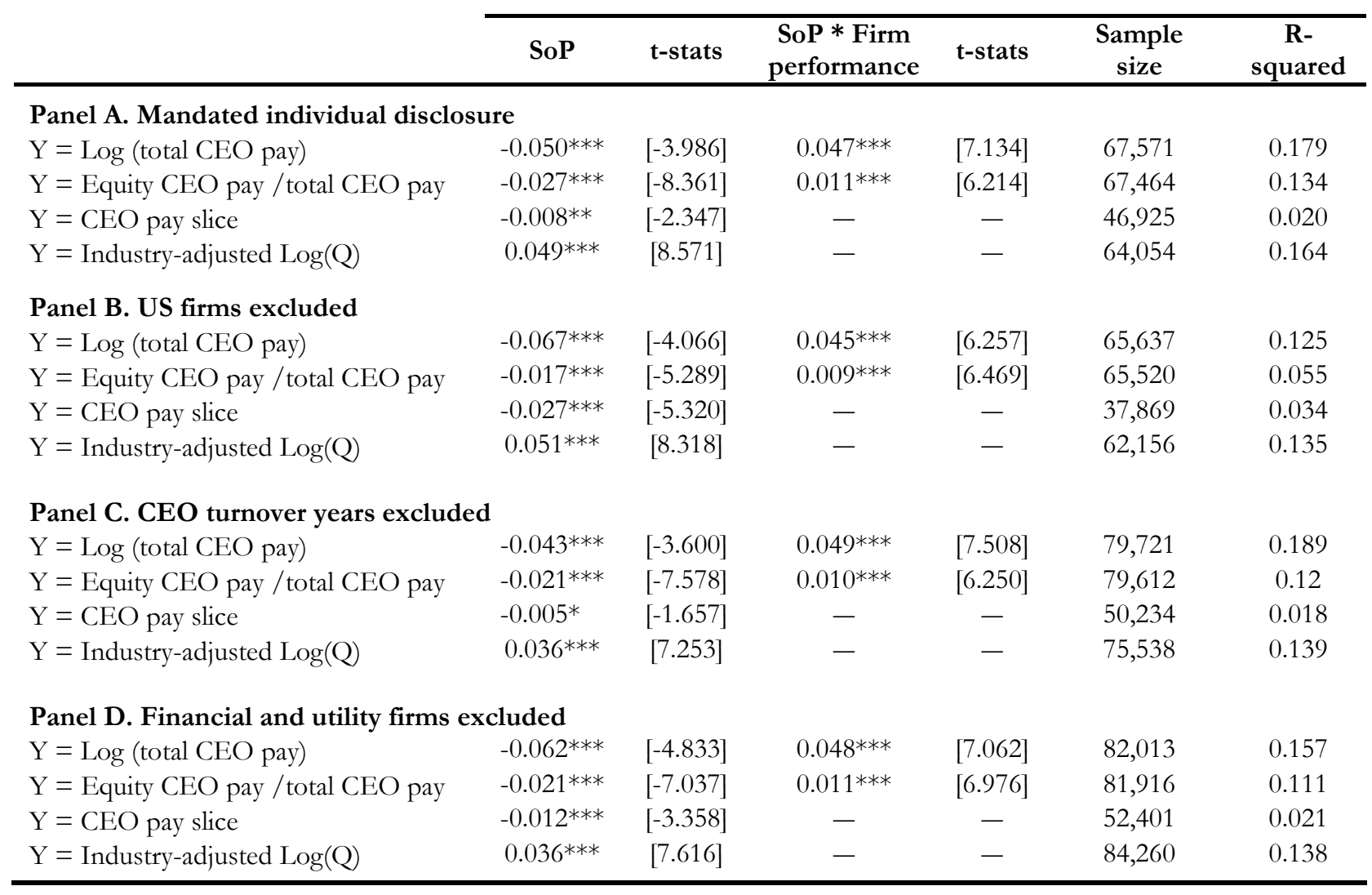




\section{Table 9. Binding versus Advisory Say on Pay Laws}

This table presents estimates of the impact of mandatory and advisory SoP laws on the level of CEO pay and the sensitivity of CEO pay to firm performance. The dependent variable is the natural logarithm of total annual CEO compensation (CEO Pay) in the first two columns, the ratio of equity-based pay to total pay for the CEO in the third column, the portion of total pay of the top 5 highest paid managers captured by the CEO in the fourth column, and the industry-adjusted log (Tobin's Q) in the final two columns. Binding (advisory) SoP laws require that the board of directors has to (does not have to) address shareholder disapproval of executive pay. Firm fixed effects along with year dummy variables are used in the estimations. Table A1 in the Appendix provides variable definitions and data sources. We winsorize all continuous variables at the one percent level and use one-year lagged values of time-varying independent variables. The t-statistics appear in brackets below parameter estimates. Robust standard errors are estimated by clustering at the firm level. Asterisks $* * *, * *$, and $*$ indicate significance at the $1 \%, 5 \%$, and $10 \%$ level, respectively.

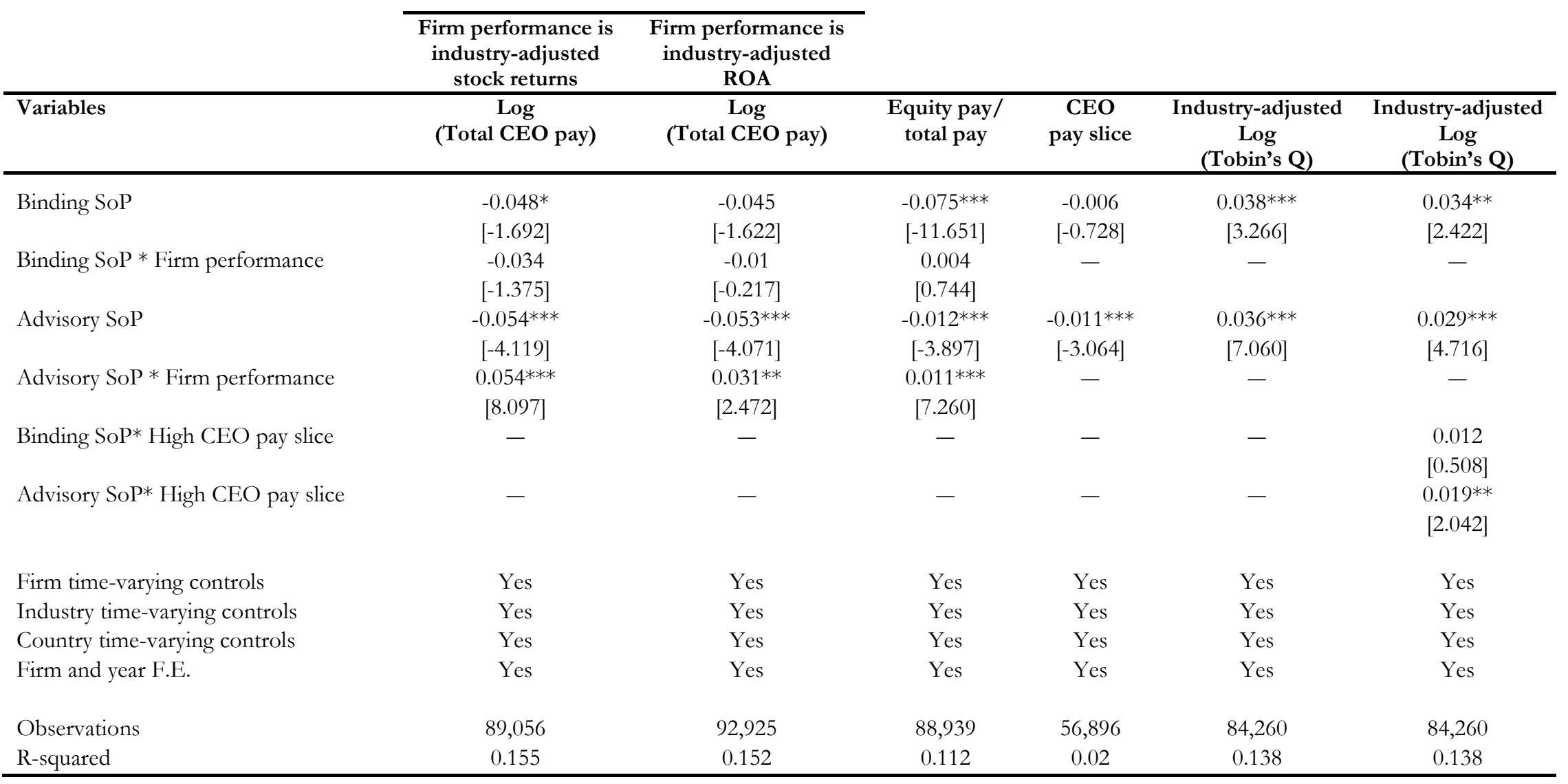




\section{Appendix}

In this appendix, we report results from several additional tests, and provide a detailed discussion of control variables in Table 2. Table 1 provides variable definitions and their data sources used in the analysis. We use one-year lagged values of time-varying variables except for variables related to CEO compensation characteristics. All continuous variables are winsorized at the one percent level. Table 2 provides results from additional robustness tests. In Table 3, we examine the impact of SoP laws on CEO pay for the subsample of firms located in countries that eventually pass a SoP law by the end of 2012. Panel A provides results for this subsample, and panel B breaks down the effects of SoP laws on CEO pay by country, where we include all the independent variables in the regression specification in column (4) of Table 2 as control variables. In this Panel, results are not reported for Denmark, Netherlands, Norway, and Portugal because the interaction term between SoP dummy and firm performance susbsumes the effects of SoP dummy due to insufficient sample size in the pre-SoP period in our firm fixed effect estimations.

\section{Table A1. Variable definitions and data sources}

\begin{tabular}{|c|c|}
\hline Variables & Definition (source) \\
\hline Total CEO pay & $\begin{array}{l}\text { Total annual compensation of the CEO, calculated as the sum of salaries, } \\
\text { bonuses, restricted stock and option awards, long-term incentive plans, } \\
\text { changes in pension plans, and all other compensation, measured in US\$. } \\
\text { (S\&P Capital IQ). }\end{array}$ \\
\hline CEO equity pay / total CEO pay & $\begin{array}{l}\text { The ratio of equity-based pay to total CEO pay, where equity-based pay is } \\
\text { the sum of stock and options awards (S\&P Capital IQ). }\end{array}$ \\
\hline CEO pay slice & $\begin{array}{l}\text { The portion of total annual compensation of the top five managers } \\
\text { captured by the CEO (S\&P Capital IQ). }\end{array}$ \\
\hline Pay gap & $\begin{array}{l}\text { The difference between CEO Pay and the median value of in total annual } \\
\text { compensation of the other top five managers. (S\&P Capital IQ). }\end{array}$ \\
\hline High CEO pay slice & $\begin{array}{l}\text { This variable equals one for firms whose abnormal CEO pay slice values } \\
\text { are greater than the country median values in the period prior to the } \\
\text { enactment of SoP laws, zero otherwise. Abnormal CEO pay slice values } \\
\text { are defined as the difference between actual levels of pay slices and their } \\
\text { estimated values obtained from fitting the regression specification in } \\
\text { column (1) of Table } 5 \text {. }\end{array}$ \\
\hline Industry-adjusted stock returns & $\begin{array}{l}\text { The total investment returns in \$US from holding the firm's stock in } \\
\text { excess of its corresponding global industry median value in a given year at } \\
\text { the level of } 2 \text {-digit SIC code. }\end{array}$ \\
\hline Industry-adjusted ROA & $\begin{array}{l}\text { The return on assets of the firm in excess of its corresponding global } \\
\text { industry median value in a given year at the level of } 2 \text {-digit SIC code } \\
\text { (Worldscope). }\end{array}$ \\
\hline Industry-adjusted $\log Q$ & $\begin{array}{l}\text { The difference between natural logarithms of the Tobin's Q of the firm } \\
\text { and the corresponding global industry median value in a given year at the } \\
\text { level of 2-digit SIC code, where Tobin's Q is the ratio of total assets plus } \\
\text { market value of equity minus book value of equity to total assets } \\
\text { (Worldscope and DataStream). }\end{array}$ \\
\hline Annualized stock return volatility & $\begin{array}{l}\text { Annualized standard deviation of daily stock returns measured in \$US } \\
\text { (Datastream). }\end{array}$ \\
\hline Net sales & Net sales of firms in US\$ in a given year (Worldscope). \\
\hline Total assets & Total assets of firms in US\$ in a given year (Worldscope). \\
\hline Leverage & Long term debt divided by the book value of total assets (Worldscope). \\
\hline Cash / total assets & The ratio of cash assets to total assets (Worldscope). \\
\hline
\end{tabular}


Capex / total assets

Inside ownership (\%)

Total institutional ownership (\%)

Independent director $\%$

Board size

Dual CEO dummy

Number of directorships

Average board directorship

CEO tenure

Grey institutional ownership (\%)

Independent institutional ownership (\%)

ADR dummy

Industry mkbk ratio

GDP growth (\%)

Inflation rate $(\%)$
The ratio of capital expenditures to total assets (Worldscope).

The percentage of a firm's shares that are closely held, where closely held shares is the number of shares owned by shareholders who hold at least $5 \%$ of the outstanding shares such as officers and directors and immediate families, other corporations, or individuals (Worldscope).

The percentage of a firm's shares that are owned by institutional investors (Global Share Ownership database).

The percentage of independent directors on the board of directors of firms (Capital IQ).

The number of directors on the board of directors of firms (Capital IQ).

The dummy variable that equals one if the $\mathrm{CEO}$ is also the chairman of the board of directors, zero otherwise (Capital IQ).

The number of directorships of the CEO (Capital IQ).

The average number of directorships for the entire board of directors (Capital IQ).

The number of years the CEO is with the firm (Capital IQ).

The percentage of a firm's shares that are owned by bank trusts, insurance companies, pension funds, and endowments (Global Share Ownership database).

The percentage of a firm's shares that are owned by mutual funds and investment advisers (Global Share Ownership database).

A dummy variable that equals one if the firm cross-lists on a US exchange or the OTC market starting with the cross-listing year, zero otherwise (JP Morgan ADR database).

The global industry median value in a given year of firms' market-to-book ratios at the level of 2-digit SIC code, where market-to-book is defined as the ratio of the market value of equity to book value of equity (DataStream database).

GDP growth measured in percentages (World Development Indicators database of World Bank and national statistical bulletins).

Inflation rate in percentages (World Development Indicators database of World Bank and national statistical bulletins). 
Table A2. Additional Robustness Regressions

\begin{tabular}{|c|c|c|c|}
\hline Variables & (1) & (2) & (3) \\
\hline SoP & $\begin{array}{l}-0.030^{*} \\
{[-1.672]}\end{array}$ & $\begin{array}{c}-0.054 * * * \\
{[-4.356]}\end{array}$ & $\begin{array}{c}-0.041 * * * \\
{[-2.909]}\end{array}$ \\
\hline Firm performance $t_{t-1}$ & $\begin{array}{c}0.034 * * * \\
{[7.304]}\end{array}$ & $\begin{array}{l}0.036^{* * *} \\
{[11.259]}\end{array}$ & $\begin{array}{c}0.033 * * * \\
{[10.466]}\end{array}$ \\
\hline SoP $*$ Firm performance ${ }_{t-1}$ & $\begin{array}{c}0.021 * * \\
{[2.187]}\end{array}$ & $\begin{array}{c}0.055^{* * *} \\
{[8.265]}\end{array}$ & $\begin{array}{c}0.049^{* * * *} \\
{[7.487]}\end{array}$ \\
\hline CEO age & $\begin{array}{c}-0.008 * * * \\
{[-7.691]}\end{array}$ & - & - \\
\hline CEO tenure & $\begin{array}{c}0.005^{* * *} \\
{[4.568]}\end{array}$ & - & - \\
\hline Firm performance $_{t}$ & - & $\begin{array}{c}0.014 * * * \\
{[4.314]}\end{array}$ & - \\
\hline SoP $*$ Firm performance ${ }_{t}$ & - & $\begin{array}{c}0.050^{* * *} \\
{[7.284]}\end{array}$ & - \\
\hline SoP $_{t-1}$ & - & - & $\begin{array}{l}0.029 * \\
{[1.947]}\end{array}$ \\
\hline SoP $_{\mathrm{t}-1} *$ Firm performance & - & - & $\begin{array}{c}0.003 \\
{[0.238]}\end{array}$ \\
\hline Log (net sales) & $\begin{array}{c}0.018^{* * *} \\
{[9.136]}\end{array}$ & $\begin{array}{c}0.018^{* * *} \\
{[15.070]}\end{array}$ & $\begin{array}{l}0.018 * * * \\
{[16.089]}\end{array}$ \\
\hline Leverage & $\begin{array}{c}-0.024 \\
{[-0.720]}\end{array}$ & $\begin{array}{l}-0.026 \\
{[-1.122]}\end{array}$ & $\begin{array}{c}-0.032 \\
{[-1.449]}\end{array}$ \\
\hline Stock return volatility & $\begin{array}{c}-2.533 * * * \\
{[-7.081]}\end{array}$ & $\begin{array}{c}-3.272 * * * \\
{[-13.100]}\end{array}$ & $\begin{array}{c}-2.596 * * * \\
{[-10.905]}\end{array}$ \\
\hline Inside ownership (\%) & $\begin{array}{c}-0.03 \\
{[-1.136]}\end{array}$ & $\begin{array}{c}-0.050 * * * \\
{[-2.769]}\end{array}$ & $\begin{array}{c}-0.046 * * \\
{[-2.570]}\end{array}$ \\
\hline Total institutional ownership (\%) & $\begin{array}{c}0.127 * * * \\
{[4.787]}\end{array}$ & $\begin{array}{c}0.172 * * * \\
{[8.854]}\end{array}$ & $\begin{array}{l}0.200^{* * * *} \\
{[10.221]}\end{array}$ \\
\hline Independent director $\%$ & $\begin{array}{c}0.02 \\
{[0.567]}\end{array}$ & $\begin{array}{c}0.056^{* * *} \\
{[2.621]}\end{array}$ & $\begin{array}{c}0.063^{* * * *} \\
{[3.024]}\end{array}$ \\
\hline Board size & $\begin{array}{c}0.020^{* * *} \\
{[8.211]}\end{array}$ & $\begin{array}{c}0.010^{* * *} \\
{[6.625]}\end{array}$ & $\begin{array}{c}0.010^{* * *} \\
{[7.236]}\end{array}$ \\
\hline Dual CEO dummy & $\begin{array}{c}-0.030^{* *} \\
{[-2.118]}\end{array}$ & $\begin{array}{c}-0.037 * * * \\
{[-3.134]}\end{array}$ & $\begin{array}{c}-0.034 * * * \\
{[-3.032]}\end{array}$ \\
\hline Log (number of directorships) & $\begin{array}{c}0.012 \\
{[0.631]}\end{array}$ & $\begin{array}{c}0.049 * * * \\
{[3.098]}\end{array}$ & $\begin{array}{c}0.054^{* * * *} \\
{[3.409]}\end{array}$ \\
\hline Industry mkbk ratio & $\begin{array}{c}-0.03 \\
{[-1.537]}\end{array}$ & $\begin{array}{c}-0.036^{* *} \\
{[-2.555]}\end{array}$ & $\begin{array}{l}-0.027^{*} \\
{[-1.959]}\end{array}$ \\
\hline GDP growth & $\begin{array}{c}0.013^{* * *} \\
{[4.014]}\end{array}$ & $\begin{array}{c}0.013^{* * *} \\
{[6.491]}\end{array}$ & $\begin{array}{c}0.012 * * * \\
{[6.232]}\end{array}$ \\
\hline Inflation & $\begin{array}{l}0.006^{*} \\
{[1.790]}\end{array}$ & $\begin{array}{c}0.005^{* *} \\
{[2.135]}\end{array}$ & $\begin{array}{c}0.005^{* * *} \\
{[2.587]}\end{array}$ \\
\hline Constant & $\begin{array}{l}13.425^{* * *} \\
{[146.049]}\end{array}$ & $\begin{array}{l}13.028^{* * *} \\
{[303.839]}\end{array}$ & $\begin{array}{l}12.922 * * * \\
{[318.125]}\end{array}$ \\
\hline $\begin{array}{l}\text { Firm F.E. } \\
\text { Year F.E. }\end{array}$ & $\begin{array}{l}\text { Yes } \\
\text { Yes }\end{array}$ & $\begin{array}{l}\text { Yes } \\
\text { Yes }\end{array}$ & $\begin{array}{l}\text { Yes } \\
\text { Yes }\end{array}$ \\
\hline $\begin{array}{l}\text { Observations } \\
\text { R-squared }\end{array}$ & $\begin{array}{c}39,654 \\
0.163\end{array}$ & $\begin{array}{c}83,575 \\
0.156\end{array}$ & $\begin{array}{c}89,056 \\
0.155\end{array}$ \\
\hline
\end{tabular}


Table A3. The Effect of SoP Laws on CEO Compensation Policies: The subsample of SoP countries

Panel A. The Sub-sample of SoP Countries

\begin{tabular}{|c|c|c|}
\hline & \\
\hline & $\begin{array}{c}\text { Firm performance is } \\
\text { industry-adjusted } \\
\text { stock returns }\end{array}$ & $\begin{array}{c}\text { Firm performance is } \\
\text { industry-adjusted } \\
\text { ROA }\end{array}$ \\
\hline Variables & (1) & $(2)$ \\
\hline \multirow[t]{2}{*}{ SoP } & -0.015 & -0.008 \\
\hline & {$[-1.053]$} & {$[-0.570]$} \\
\hline \multirow[t]{2}{*}{ Firm performance } & $0.029 * * *$ & 0.01 \\
\hline & {$[5.401]$} & {$[0.858]$} \\
\hline \multirow[t]{2}{*}{ SoP $*$ Firm performance } & $0.055^{* * *}$ & $0.055^{* *}$ \\
\hline & {$[6.744]$} & {$[2.500]$} \\
\hline \multirow[t]{2}{*}{ Log (net sales) } & $0.016^{* * *}$ & $0.015^{* * *}$ \\
\hline & {$[7.644]$} & {$[7.570]$} \\
\hline \multirow[t]{2}{*}{ Leverage } & -0.068 & -0.045 \\
\hline & {$[-1.639]$} & {$[-1.104]$} \\
\hline \multirow[t]{2}{*}{ Stock return volatility } & $-3.431 * * *$ & $-3.070^{* * *}$ \\
\hline & {$[-8.653]$} & {$[-8.044]$} \\
\hline \multirow[t]{2}{*}{ Inside ownership (\%) } & $-0.084 * * *$ & $-0.086 * * *$ \\
\hline & {$[-3.039]$} & {$[-3.256]$} \\
\hline \multirow[t]{2}{*}{ Total institutional ownership (\%) } & $0.052 * *$ & $0.064 * * *$ \\
\hline & {$[2.159]$} & {$[2.729]$} \\
\hline \multirow[t]{2}{*}{ Independent director $\%$} & $0.094 * *$ & $0.101 * * *$ \\
\hline & {$[2.557]$} & {$[2.786]$} \\
\hline \multirow[t]{2}{*}{ Board size } & $0.013^{* * *}$ & $0.013 * * *$ \\
\hline & {$[4.385]$} & {$[4.578]$} \\
\hline \multirow[t]{2}{*}{ Dual CEO dummy } & $-0.028^{*}$ & -0.023 \\
\hline & {$[-1.817]$} & {$[-1.538]$} \\
\hline \multirow[t]{2}{*}{ Log (number of directorships) } & 0.025 & 0.03 \\
\hline & [1.012] & [1.209] \\
\hline \multirow[t]{2}{*}{ Industry mkbk ratio } & $-0.047 * *$ & $-0.059 * * *$ \\
\hline & {$[-2.372]$} & {$[-3.068]$} \\
\hline \multirow[t]{2}{*}{ GDP growth } & $0.008^{* *}$ & $0.013 * * *$ \\
\hline & {$[2.254]$} & {$[3.528]$} \\
\hline \multirow[t]{2}{*}{ Inflation } & -0.0001 & 0.002 \\
\hline & {$[-0.028]$} & {$[0.640]$} \\
\hline \multirow[t]{2}{*}{ Constant } & $13.451 * * *$ & $13.441 * * *$ \\
\hline & {$[195.822]$} & {$[200.261]$} \\
\hline Firm F.E. & Yes & Yes \\
\hline Year F.E. & Yes & Yes \\
\hline Observations & 50,175 & 52,434 \\
\hline R-squared & 0.18 & 0.174 \\
\hline Number of fid & 9,417 & 9,767 \\
\hline
\end{tabular}


Panel B. Country by Country Regressions

\begin{tabular}{lcccccc}
\hline Country & SoP & t-stats & $\begin{array}{c}\text { SoP * Firm } \\
\text { performance }\end{array}$ & t-stats & $\begin{array}{c}\text { Sample } \\
\text { size }\end{array}$ & R-squared \\
\hline Australia & $1.408^{* * *}$ & {$[5.104]$} & $0.093^{* * *}$ & {$[3.431]$} & 10,549 & 0.129 \\
Belgium & -0.643 & {$[-0.713]$} & - & - & 260 & 0.134 \\
South Africa & $0.294^{* * *}$ & {$[2.695]$} & -0.017 & {$[-0.211]$} & 2,034 & 0.268 \\
Sweden & 0.802 & {$[0.678]$} & -0.05 & {$[-0.531]$} & 1,096 & 0.065 \\
United Kingdom & $0.975^{* * *}$ & {$[9.110]$} & 0.014 & {$[0.576]$} & 11,001 & 0.110 \\
United States & $0.245^{* * *}$ & {$[4.532]$} & $0.110^{* * *}$ & {$[4.358]$} & 23,419 & 0.263 \\
\hline
\end{tabular}




\section{Discussion of Results on Control Variables in Table 2}

Higher values of leverage and volatility represent more firm risk, for which the CEO may demand a higher premium in the form of greater pay. We find in Table 2 that leverage has no effect on CEO compensation while the coefficient on stock return volatility is negative and statistically significant. Fernandes et al. (2013) find similar effects of firm risk in their analysis of the US pay premium in a firm fixed effects model. They argue that such negative correlation may be a result of the noise induced by CEO's effect on firm performance as stated by Lazear and Rosen (1981), which can result in lower expected pay.

It is unclear based on the empirical evidence whether inside ownership should be negatively or positively related to CEO compensation. Higher levels of inside ownership can translate into powerful and entrenched CEOs and thus a lower degree of monitoring of managers (e.g., Boone et al. (2004)). However, inside ownership can also reflect the presence of blockholders, which may be associated with a greater degree of monitoring of the CEO. Further, CEOs with high shareownership get compensated mainly through changes in the market values of their shareholdings, and direct compensation likely constitutes a smaller portion of such changes in their wealth, implying that inside ownership may not be related to CEO pay. Column (3) in Table 2 shows a negative coefficient on the percentage of shares owned by corporate insiders. We also observe that a higher percentage of institutional ownership is related to higher CEO pay levels, which is consistent with the empirical evidence (e.g., Fernandes et al. (2013)). Smaller boards and greater percentage of independent directors on board are generally viewed as better monitoring of the management (e.g., Dahya, Dimitrov, and McConnell (2008), Core et al. (1999), Yermack (1996)). The results in column (4) of Table 2 show that a greater independent director percentage is positively related to CEO pay, consistent with Core, Holthausen, and Larcker (1999), but smaller boards are associated with lower pay. We also control for whether the CEO serves as the chairman of the board (dual CEO dummy). The empirical evidence provides mixed evidence on whether such dual roles of CEOs are a symptom of CEO power and poor governance, and whether they have any impact on firm value. We find that the CEOs with a dual role have lower CEO compensation, which is similar to our finding on inside ownership percentage, as the probability of observing a dual CEO role within a firm is closely related to managerial shareholdings. Finally, we find that a greater number of directorships a CEO holds, the larger is her pay level. This finding is consistent with the notion that multiple directorships are indications of superior managerial talent (e.g., Ferris, Jagannathan, and Pritchard (2003)). This table also reports that GDP growth and inflation rate are positively related to CEO compensation. 